\title{
Mass balance observations and reconstruction for Batysh Sook Glacier, Tien Shan, from 2004 to 2016
}

\author{
Ruslan Kenzhebaev ${ }^{\mathrm{a}, *}$, Martina Barandun ${ }^{\mathrm{b}}$, Marlene Kronenberg ${ }^{\mathrm{b}, \mathrm{d}}$, Yaning Chen ${ }^{\mathrm{a}, *}$, \\ Ryskul Usubaliev ${ }^{\mathrm{c}}$, Martin Hoelzle ${ }^{\mathrm{b}}$ \\ a State Key Laboratory of Desert and Oasis Ecology, Xinjiang Institute of Ecology and Geography, Chinese Academy of Sciences, Urumqi, 830011, China \\ b Department of Geoscience, University of Fribourg, Fribourg, Switzerland \\ ${ }^{\mathrm{c}}$ Central Asian Institute of Applied Geosciences (CAIAG), Bishkek, Kyrgyzstan \\ d Meteodat GmbH, Zurich, Switzerland
}

\begin{abstract}
In this study we present an analysis of measured annual mass balances for the period 2011 to 2016 and a reconstruction of seasonal mass balances from 2004 to 2010 for Batysh Sook Glacier located in the Kyrgyz Tien Shan. Conventional methods and a model-based extrapolation of the point measurements were used to obtain glacier-wide mass balances and to analyze glaciological measurements. Especially at the beginning of the reestablished glacier mass balance monitoring program, deviations between the different methods were significant, having a range of $0.40 \mathrm{~m}$ w.e. $\mathrm{a}^{-1}$. With the improvement of the measurement network in later years, the results of the different extrapolation methods showed better agreement (range of 0.10 to $0.22 \mathrm{~m}$ w.e. $\mathrm{a}^{-1}$ ). For 2011 to 2016 , the profile method revealed a mass loss of $-0.41 \pm 28 \mathrm{~m}$ w.e. $\mathrm{a}^{-1}$. The contour line method yielded a negative mean mass balance of $-0.34 \pm 20 \mathrm{~m}$ w.e $\mathrm{a}^{-1}$, whereas the model-based extrapolation clearly resulted in the most negative value of $-0.43 \pm 16 \mathrm{~m}$ w.e. $\mathrm{a}^{-1}$ for the same period.

The same distributed accumulation and temperature index melt model used to extrapolate point measurements from 2011 to 2016 was applied in order to reconstruct the mass balance from 2004 to 2010. The model was driven by daily air temperature and precipitation data from a nearby meteorological station and the model parameters were calibrated with in-situ measurements of annual mass balances collected from 2011 to 2016. Winter accumulation measurements taken in May 2014 were used for calibration purposes and to deduce snow distribution patterns. Subseasonal model performance was validated based on the snow cover depletion pattern observed on satellite images during the summer months from 2004 to 2016. For Batysh Sook Glacier an average annual mass balance of $-0.39 \pm 0.26 \mathrm{~m}$ w.e. $\mathrm{a}^{-1}$ was found for the period 2003/04 to 2015/16.
\end{abstract}

\section{Introduction}

Glaciers located in high mountain areas such as the Kyrgyz Tien Shan are indispensable water reservoirs (Kaser et al., 2010; Immerzeel et al., 2010). Changes in glacier mass are a key focus of glacier monitoring program which aims to assess climate change and evaluate water resources (Zemp et al., 2015). The inhabitants of arid and semi-arid lowlands in Central Asia are highly dependent on the water originating in mountain areas (Narama et al., 2010; Lutz et al., 2013; Kriegel et al., 2013). The water volume in Kyrgyzstan is estimated at $2458 \mathrm{~km}^{3}$, of which $50 \mathrm{~km}^{3}$ stems from surface river runoff and $13 \mathrm{~km}^{3}$ from ground water reserves. Of the remainder, $1745 \mathrm{~km}^{3}$ is stored in lakes, and approx. $650 \mathrm{~km}^{3}(26 \%$ of the total volume) in glacier ice and snow (Mamatov et al., 2004).

\footnotetext{
* Corresponding authors.

E-mail addresses: rusi89@mail.ru (R. Kenzhebaev), chenyn@ms.xjb.ac.cn (Y. Chen).
}

The total water storage of the Tien Shan has a strong decreasing trend with an annual average of $-3.72 \mathrm{~mm} \mathrm{a}^{-1}$ (Chen et al., 2016). This trend is expected to increase in future, leading to an important water shortage for the next half-century (Chen et al., 2016). Considering the major contribution of fresh water stored in the Kyrgyz Mountains, a detailed understanding of the evolution of Tien Shan glaciers as an important component of the cryosphere is of crucial interest. Improved model-based assessments are a prerequisite for sound estimates of future water availability and natural hazards in the context of climate change (Unger-Shayesteh et al., 2013; Sorg et al., 2014).

Various authors have detected substantial glacier area decreases in the Tien Shan using remote sensing techniques (e.g. Vilesov and Uvarov, 2001; Khromova et al., 2003; Jing et al., 2006; Li et al., 2006; Hagg et al., 2007; Bolch, 2007; Ozmonov et al., 2013; Petrakov et al., 2016). Glacier volume assessments from satellite surveys confirm a trend toward mass loss over the recent decades for the Central and 
Inner Tien-Shan (e.g. Aizen et al., 2006; Pieczonka et al., 2013; Gardner et al., 2013; Wu et al., 2014; Pieczonka and Bolch, 2015; Farinotti et al., 2015; Petrakov et al., 2016).

In addition to such remote sensing approaches, long-term glaciological mass balances facilitate a better process understanding, calibration/validation of mass balance models and their application for future projections at Central Asian glaciers and water resources. In-situ glacier mass balance measurements have been rare in the Tien Shan, especially since the mid-1990s, when several long-term glacier monitoring programs were discontinued (WGMS, 2012; Sorg et al., 2012; Unger-Shayesteh et al., 2013). During the Soviet regime, glaciological measurements were performed on selected glaciers. In the Kyrgyz Tien Shan, Golubin Glacier (Ala Archa region, Northern Tien Shan), Glacier No. 131, Davydov, Gregoriev, Karabatkak, Sary-Tor and Batysh Sook Glaciers (all in the Inner Tien Shan) were investigated to a thorough extent (Fig. 1) (e.g. Dyurgerov et al., 1994; Dyurgerov and Mikhalenko, 1995; Kronenberg et al., 2016).

Batysh Sook Glacier (in earlier studies also known as Suyok (Suek) Zapadniy Glacier or Glacier No. 419), was observed during short periods in 1970/71, 1983/84 and from 1988 to 1991 (WGMS, 1998). In 2010, the glacier was chosen for long-term monitoring by a group of researchers from Kyrgyzstan, Germany and Switzerland as a part of the Central Asian Water (CAWa) and Capacity Building and Twinning for Climate Observing Systems (CATCOS) projects. Since then, glaciological measurements have been carried out continuously thanks to the joint efforts of local and international scientists.

The main goals of this study are: (1) to analyze the seasonal glacier-wide mass balance of Batysh Sook Glacier from 2010/11 to 2015/16 using different conventional extrapolation methods and a model-based extrapolation of the glaciological measurements, and (2) to reconstruct the mass balance from 2003/04 to 2009/10 based on the application of a distributed mass balance model. The model was calibrated using in-situ measurements of both annual mass balance collected from 2010/11 to 2015/16 and winter accumulation measurements from May 2014. The subseasonal model performance was validated based on the observation of snow cover depletion patterns on Landsat satellite images.

\subsection{Study area and data}

The Tien Shan is a vast mountain system in Central Asia (Fig. 1). Batysh Sook Glacier $\left(41^{\circ} 46.668^{\prime} \mathrm{N}, 77^{\circ} 45.071^{\prime} \mathrm{E}\right)$ is located within the Sook range, Inner Tien Shan. The Sook range consists of 44 glaciers with a total area of $30.9 \mathrm{~km}^{2}$ and a volume of $1.2 \mathrm{~km}^{3}$, as estimated in 2007 (Hagg et al., 2013). From 1956 to 2007, these glaciers lost over $12 \%$ of their volume (Hagg et al., 2013). Batysh Sook Glacier spans an altitudinal range of 3950 to $4450 \mathrm{~m}$ a.s.l and in 2016 covers an area of around $1.08 \mathrm{~km}^{2}$.

The mean annual temperature measured at the Tien Shan Kumtor automatic weather station, (AWS) situated in the Akshiirak massive at an elevation of $3660 \mathrm{~m}$ a.s.l, is $-5.8^{\circ} \mathrm{C}(2003-2014)$. The warmest month is July with an average temperature of $4.4^{\circ} \mathrm{C}$ (2003-2014, Fig. 2) and the lowest temperatures are measured in January, with a long-term mean value of $-21.6{ }^{\circ} \mathrm{C}$ (1930-1996, Kutuzov and Shahgedanova, 2009). Mean annual precipitation is $360 \mathrm{~mm}$ (2003-2014), and on a long-term perspective (1930-1996) up to $76 \%$ of the annual precipitation was recorded during the summer months (May-September) (Kutuzov and Shahgedanova, 2009).

The Tien Shan Kumtor AWS started to operate on the 19th of August 1996, replacing the former Tien Shan station located nearby. The new AWS is situated at a distance of $32 \mathrm{~km}$ from Batysh Sook and records data every hour. Daily precipitation totals and daily mean temperatures are calculated for the use as model input. Monthly temperature lapse rates calculated by Aizen et al. (1995) from six stations in the Central Tien Shan are used to extrapolate the temperature data to the mean glacier elevation (Kronenberg et al., 2016).

Annual glacier outlines are digitized manually from Landsat images with suitable quality (Table 1). For 2005 no suitable image is available and outlines from the previous year are adopted. For topography, the Shuttle Tomography Mission (SRTM) DEM v3 from February 2000 is downscaled to a pixel size of $20 \mathrm{~m}$ to match the model resolution. The topography is kept constant for the considered period due to the lack of data. To test the effect of the unchanged glacier elevation, a sensitivity analysis is performed described in the section "Uncertainty analysis".

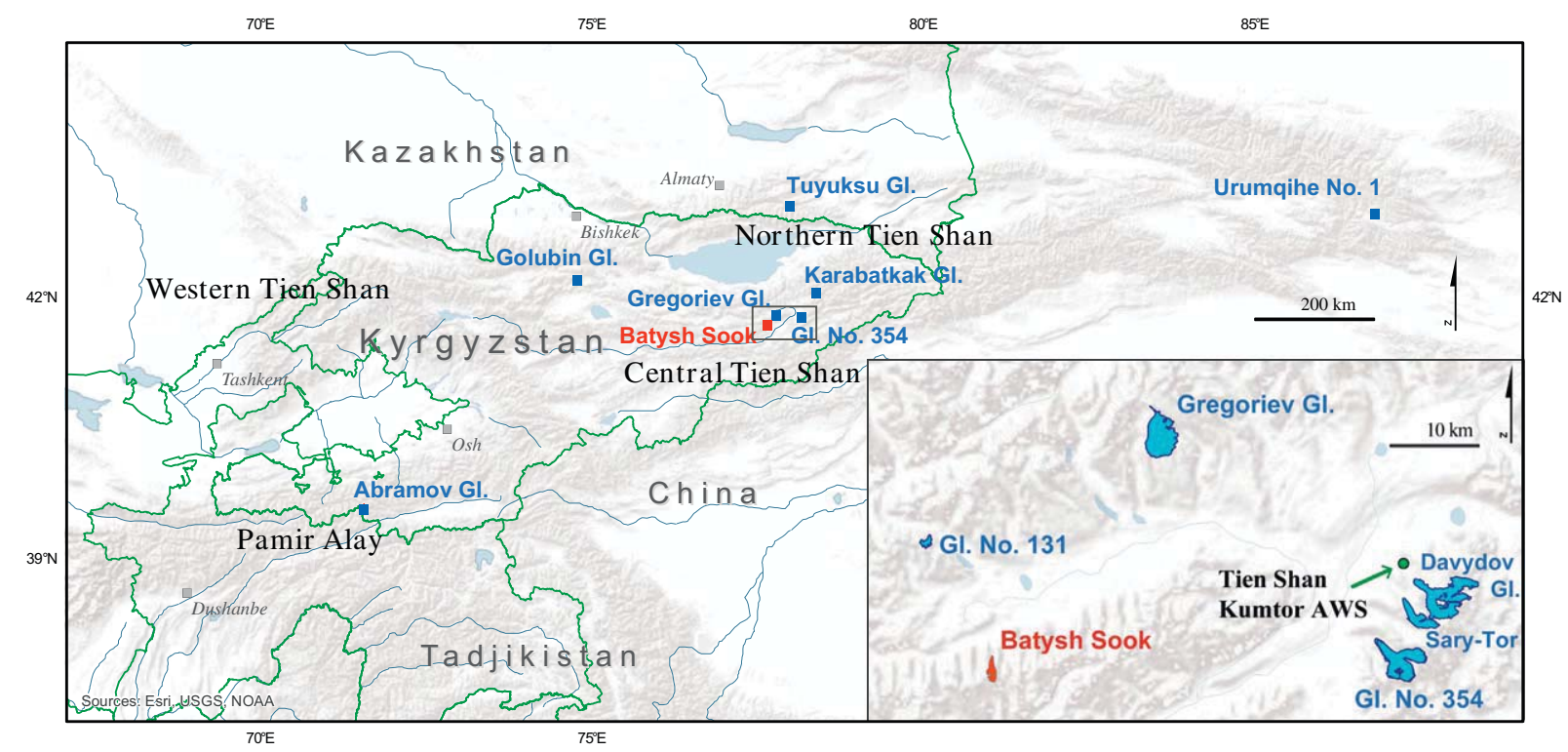

Fig. 1. Location map of Batysh Sook Glacier, Inner Tien Shan, Kyrgyzstan. The black square indicates the inset and shows a zoom into the study area. Indicated are former and currently monitored glaciers and the Tien Shan Kumtor automatic weather station (AWS).

Source: Environmental Systems Research Institute (ESRI)/US Geological Survey/US National Oceanic and Atmospheric Administration. 


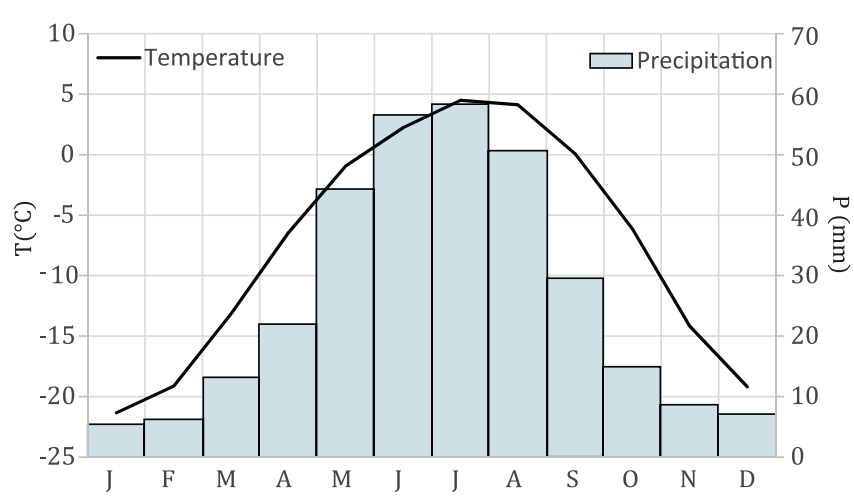

Fig. 2. Monthly precipitation totals (bars) and air temperature averages (line) for the Tian Shan Kumtor AWS (3660 m a.s.l.) during the period 2003 to 2014 (modified after Kronenberg et al. (2016)).

\subsubsection{Glaciological mass balance data}

The re-establishment of the glacier long-term monitoring program in 2010/11 included an observation network of seven stakes and two snow pits measured at annual visits in late summer. Observation dates are constrained by access and logistics and could not be tied to the end of the hydrological year (end of September). Thus, observations periods vary considerably from year to year. The monitoring network has been improved annually to increase the representativeness of ablation and accumulation measurements to a total of 14 stakes and four snow pits in 2016 (Fig. 3a and Table 2). Ablation is measured using wooden and plastic stakes, which are drilled into the ice with a Heucke steam drill. When melted out, the stakes are replaced at the original location to account for ice flow. Point ablation measurements are converted to water equivalent by using an ice density of $900 \mathrm{~kg} \mathrm{~m}^{-3}$. In the accumulation area, snow pits are dug to the previous year's summer horizon to measure snow depth and density. Density is determined gravimetrically for each pit. Snow probings are taken following the path of observers along the various snow pits in order to cover an area as large as possible in the accumulation zone. For each probing location, a sample of three probes is taken to prevent outliers. The measured density in the snow pits is used to convert snow probings into water equivalent. In May 2014, winter snow accumulation distribution with two snow pits and 200 densely spaced snow depth measurements distributed over the entire glacier area were collected (Fig. 3b). Further information on mass balance data can be obtained from the World Glacier Monitoring Service (WGMS, 2014).

Table 1

Input data for topography, outlines and for glacier snowline mapping.

\begin{tabular}{llllll}
\hline $\begin{array}{l}\text { Sensor } \\
\text { SRTM-DEM V3 }\end{array}$ & $\begin{array}{l}\text { Date } \\
\text { Feb 2000 }\end{array}$ & & & & \\
\hline Landsat 5 & 12.06 .2006 & 08.07 .2007 & 13.07 .2007 & 24.07 .2007 & 05.04 .2008 \\
& 07.05 .2008 & 27.06 .2009 & 26.05 .2009 & 11.05 .2009 & 18.07 .2009 \\
& 16.05 .2010 & 12.07 .2011 & & & \\
Landsat 7 & 14.06 .2004 & 04.05 .2004 & 18.04 .2004 & 11.04 .2004 & 26.05 .2006 \\
& 13.07 .2006 & 17.07 .2007 & 18.07 .2008 & 02.07 .2008 & 10.08 .2009 \\
& 27.06 .2010 & 21.08 .2010 & 06.09 .2010 & 24.05 .2011 & 27.07 .2011 \\
& 11.06 .2012 & 29.07 .2012 & 28.08 .2012 & 01.08 .2013 & 09.07 .2013 \\
& 14.04 .2014 & 09.05 .2014 & 25.05 .2014 & 01.06 .2014 & 28.06 .2014 \\
Landsat 8 & 15.07 .2014 & 31.07 .2014 & 01.09 .2014 & 11.07 .2015 & 23.09 .2016 \\
& 30.05 .2013 & 06.06 .2013 & 04.08 .2013 & 08.07 .2013 & 24.07 .2013 \\
& 04.08 .2013 & 01.05 .2014 & 28.06 .2014 & 11.07 .2014 & 10.07 .2015 \\
& 20.08 .2015 & 04.06 .2016 & 22.06 .2016 & 08.08 .2016 & 15.09 .2016 \\
\hline
\end{tabular}

\section{Methods}

2.1. Conventional extrapolation methods to determine glacier-wide mass balance

Three different methods are used to analyze the glaciological mass balance: (1) the profile method, (2) the contour line method and (3) a model-based extrapolation.

The profile method is based on the assumption that local mass balance values vary as a function of elevation $f(z)$ only (Escher-Vetter et al., 2009). The mass balance ( $B_{\text {profile }}$ ) is the integration of $f(z)$ over the entire glacier area $\left(A_{\text {glacier }}\right)$ :

$\mathrm{B}_{\text {profile }}=\frac{\sum_{i=0}^{n} f\left(z_{i}\right) A\left(z_{i}\right)}{A_{\text {glacier }}}$.

Here we analyze the mass balance for $100 \mathrm{~m}$ elevation bands, each with an area $(A)$. For the ablation area we define $f\left(z_{i}\right)$ as the linear regression fitted to all annual ablation measurements using generalized least squares. The equilibrium-line altitude (ELA) is extrapolated using the ablation gradient. In the accumulation area, mass balance values do not show a strict relation to elevation but express a more complex distribution. To avoid overestimation of accumulation rates at high elevations, we used the mean of all point measurements in the accumulation zone to define a constant $f\left(z_{i}\right)$ for the accumulation area.

Applying the contour line method, lines of equal specific mass balance (isopleths) are manually drawn based on point measurements and expert knowledge (Kaser et al., 2003). In this way, surface mass balance, topography, terrain characteristics, snow relocation processes and elevation can be taken into consideration by the observer (Ostrem and Brugman, 1991). We use a constant interval of $0.50 \mathrm{~m}$ w.e. $\mathrm{a}^{-1}$ for the isopleths. The lines are drawn manually over the glacier area $\left(A_{\text {glacier }}\right)$ in ArcGIS and the mass balance is interpolated between the lines (TopoToRaster interpolation). The interpolation pattern is carefully checked afterwards to prevent artefacts due to the interpolation algorithm. A mean mass balance $\left(b_{i}\right)$ is then calculated for each individual zone. The mass balance value is multiplied by the area $\left(A_{i}\right)$ of each zone, totalled and then divided by the total glacier surface area (Aglacier) to obtain the mean specific mass balance $\left(B_{\text {contour }}\right)$ :

$\mathrm{B}_{\text {contour }}=\frac{\sum_{i=1}^{n} b_{i} * A_{i}}{A_{\text {glacier }}}$.

To calculate the mean mass balance per $100 \mathrm{~m}$ elevation band, the zones of equal mass balance are intersected with the elevation bands in ArcGIS. From this, the ELA can be deduced.

\subsection{Model-based extrapolation to determine glacier-wide mass balance}

We evaluated the in-situ point mass balance data for the period 2010/11-2015/16 with a mass balance model. The model is a combined distributed accumulation (Huss et al., 2008) and temperature index melt model (Hock, 1999), which was previously used to analyze mass balance for a glacier located in the same region (Kronenberg et al., 2016). Surface ablation and accumulation is calculated for each grid cell (20 m resolution) and each day of the year. The model is, thus, capable of resolving glacier-wide mass balance on (1) a daily resolution, including the main mass balance processes, and (2) for an arbitrarily chosen period, e.g. the hydrological year (here from the beginning of October to the end of September).

Ablation is calculated on the basis of melt factors, which are varied as a function of potential clear-sky direct solar radiation $\left(I_{p o t}\right)$. This term for radiation is calculated individually for each grid cell and thereby allows 

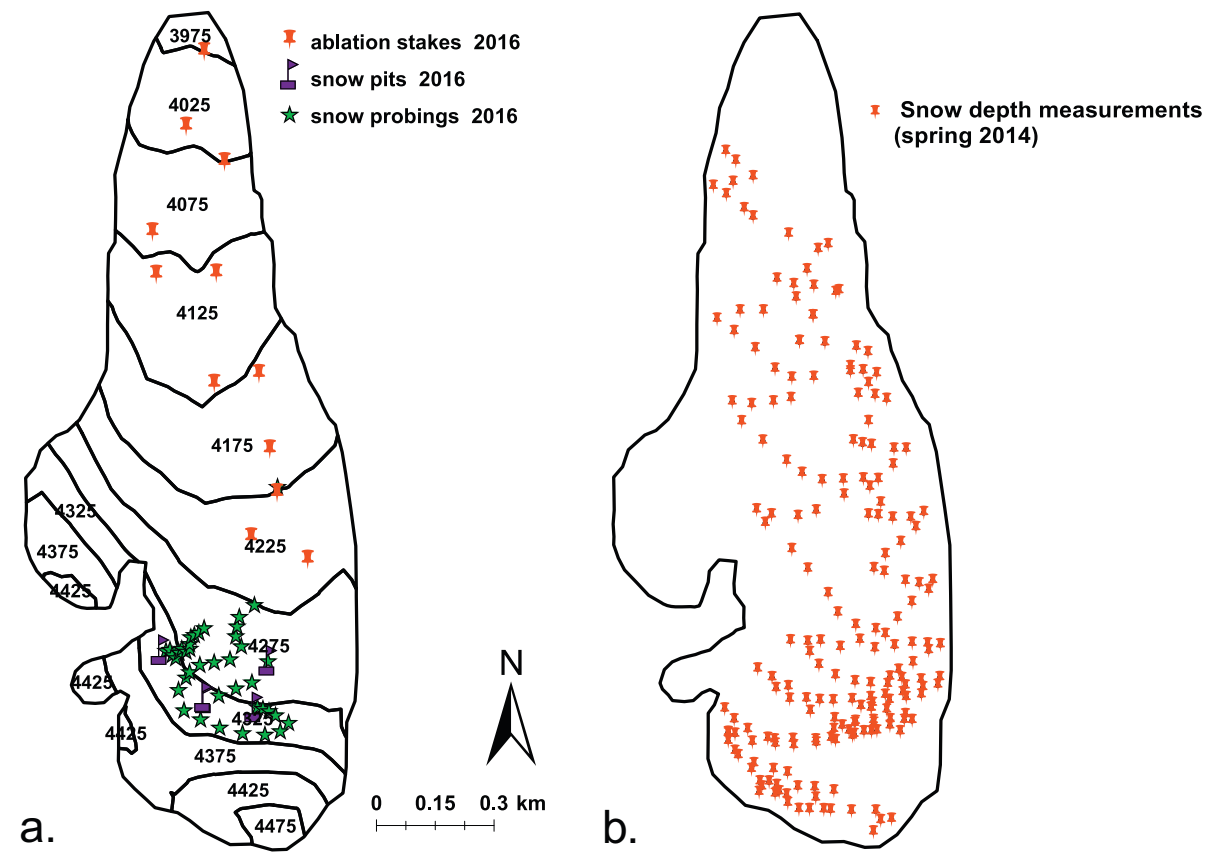

Fig. 3. Observation network on Batysh Sook Glacier in 2016. Annual mass balance was measured every year. Observation dates range between 17 th of July and 13 th of September for 2010/ 11 to 2015/16. (a) The locations of ablation stakes, snow probings and snow pits are indicated. (b) In May 2014, snow depth measurements were performed.

the effects of slope and aspect to be accounted for (Hock, 1999). The daily $(t)$ surface melt rates $(M)$ for a grid cell $(x, y)$ are calculated as:

$M_{(x, y, t)}=\left\{\begin{array}{cl}\left(f_{M}+r_{\text {snow } / i c e} I_{\text {pot }(x, y)}\right) * T_{(x, y, t)}: & T>0{ }^{\circ} \mathrm{C} \\ 0 \quad & T \leq 0{ }^{\circ} \mathrm{C}\end{array}\right.$

where $f_{M}$ is a melt factor and $r_{\text {snow/ice }}$ are radiation factors for snow and ice surfaces. Here, the air temperature $(T)$ is extrapolated from the mean glacier elevation to every grid cell using a constant lapse rate of $d T /$ $d z .=-7.3^{\circ} \mathrm{C} \mathrm{km}^{-1}$. The value for $d T / d z$. corresponds to the average monthly lapse rate for which melt is expected for the Central Tien Shan published in Aizen et al. (1995). The lapse rate is held constant. Accumulation is calculated from solid precipitation, which is defined as occurring when air temperatures lies below a threshold temperature $\left(T_{t h r}=1.5^{\circ} \mathrm{C}\right)$ (e.g. Hock, 1999). The accumulation rate $(C)$ is based on solid precipitation measured at the meteorological station $\left(P_{w s}\right)$ for each day $(t)$ and each grid cell $(x, y)$ :

$C(x, y, t)=P_{W S}(t) * c_{\text {prec }} * D_{\text {snow }}(x, y)$

A correction factor $\left(c_{\text {prec }}\right)$ enables the adjustment of precipitation totals to account for systematic errors such as gauge under-catch and differences between the measurement locations. $C_{\text {prec }}$ varies for summer $\left(c_{\text {prec_summer }}\right)$ and winter $\left(c_{\text {prec_winter }}\right)$ due to varying measurement errors related to the type of precipitation (solid/liquid, wet/dry

Table 2

Amount of in-situ measurements since the re-establishment of the glacier monitoring of Batysh Sook Glacier in 2010.

\begin{tabular}{llll}
\hline Date & Stakes & Snow pits & Probings \\
\hline $01 / 09 / 2010$ & 7 & - & - \\
$20 / 08 / 2011$ & 7 & 3 & - \\
$27 / 08 / 2012$ & 9 & 3 & 13 \\
$26 / 07 / 2013$ & 10 & 1 & - \\
$16 / 05 / 2014$ & 10 & 2 & $\sim 200$ \\
$29 / 08 / 2014$ & 10 & 2 & 12 \\
$07 / 08 / 2015$ & 12 & 3 & 17 \\
$17 / 07 / 2016$ & 14 & 4 & 34 \\
$13 / 09 / 2016$ & 14 & 2 & 6 \\
\hline
\end{tabular}

snow). Accumulation via solid precipitation during summer and winter months can vary in continental regions due to different conditions during snow deposition. As the snow during winter months is deposited under very cold conditions, the snow is dry and can be transported easily by means of wind. By contrast, during summer month snow is more likely to be deposited in a wetter state and thus wind displacement is diminished and further limited by fast ice crust formation (called Firnspiegel) due to strong radiation and higher temperature conditions. For this reason, the gauge under-catch is more pronounced in the winter than in the summer months.

A dimensionless spatial snow distribution multiplier $\left(D_{\text {snow }}\right)$ (Tarboton et al., 1995; Farinotti et al., 2010) accounts for the spatial variability of the snow distribution over the glacier. $\mathrm{D}_{\text {snow }}(\mathrm{x}, \mathrm{y})$ is derived by spatially interpolating a dense network of snow depth measurements distributed over the entire glacier area with an enhanced inverse-distance scheme (Fig. 4). The scheme has a search radius of $150 \mathrm{~m}$ around each grid cell increasing stepwise until at least three measurements are found. In a second step, a grid including the small-scale variability is combined with the grid produced by means of inverse distance interpolation. This index-based grid takes into account: (1) terrain curvature, (2) slope, and (3) elevation. The curvature is evaluated around each grid cell. Concave grid cells are attributed more snow whereas convex cells receive less snow. A linear relation relates the degree of curvature to the snow distribution. Snow accumulation is reduced linearly with slope increasing from $40^{\circ}$ to $60^{\circ}$. Slopes steeper than $60^{\circ}$ are set to zero accumulation (Huss et al., 2008). Snow distribution is fixed to decrease linearly above a critical elevation (here: $4400 \mathrm{~m}$ a.s.l.) where wind processes relocate snow and hamper accumulation. Thus, processes of preferential deposition of snow, as well as snowdrift are indirectly included in the model (Huss et al., 2009). This snow distribution map is then normalized to an average of 1. We assume that the spatial snow distribution does not change significantly from one year to another (e.g. Helfricht et al., 2014). Observations in May 2014 are thus used for all years without extensive winter surveys. The impact of this assumption is analyzed by means of a sensitivity experiment proposed in Kronenberg et al. (2016) and further described in the "uncertainty analysis". 


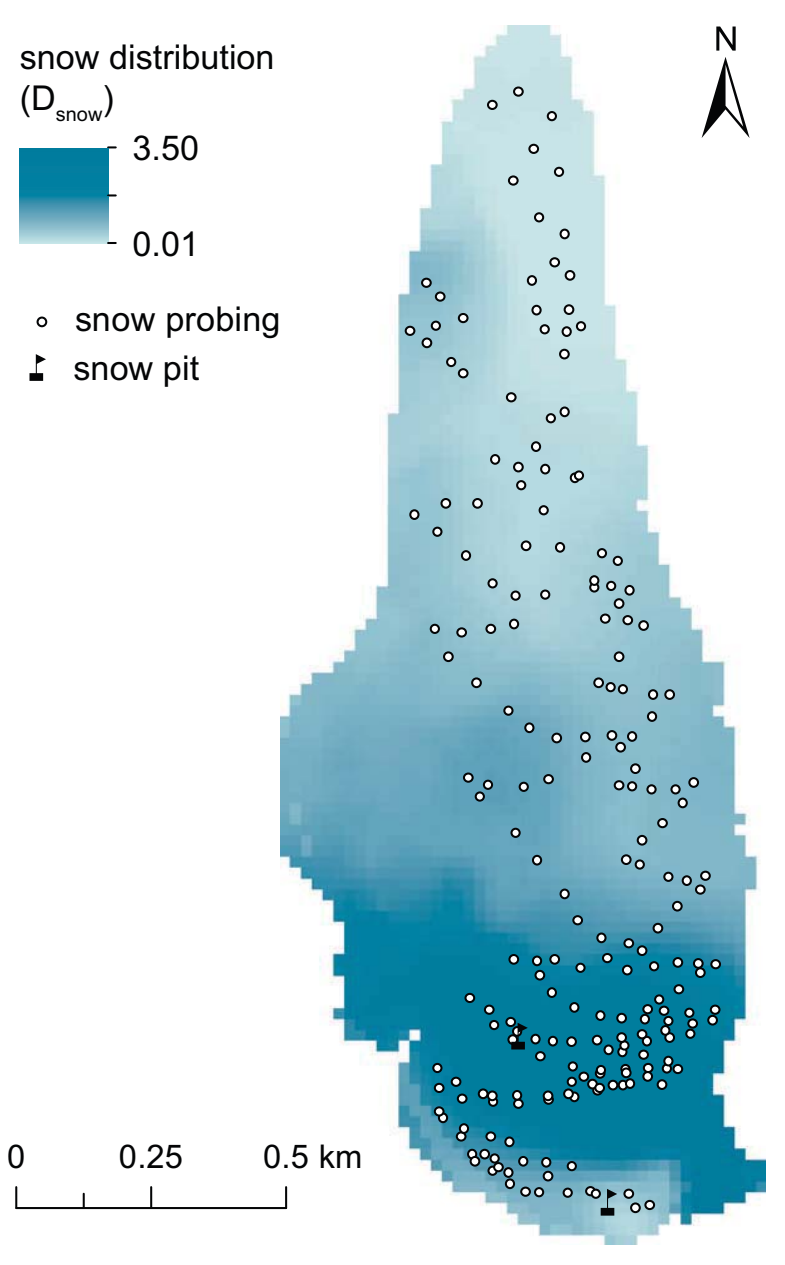

Fig. 4. Modelled snow distribution $\left(D_{\text {snow }}\right)$ is normalized to an average of one. $D_{\text {snow }}$ is derived from a dense snow probing network obtained in May 2014. Snow pits and snow probes from May 2014 are indicated additionally.

The mass balance model is calibrated using the available measurements to provide a consistent mass balance time series for the hydrological years from 2010/11 to 2015/16. Thus, by using an iterative procedure, modelled mass balances are fitted to best represent the direct observations. The melt parameters $F_{M}, r_{\text {snow }}$ and $r_{i c e}$ are adjusted automatically in order to minimize the root-mean-square error (RMSE) with point measurements for each year individually (Table 3). For $2014, c_{\text {prec_winter }}$ is constrained by direct winter accumulation measurements and reduced by a factor of 0.25 for the summer months $\left(c_{\text {prec_summer }}\right)$. For all other years with annual mass balance surveys but no winter measurements, $c_{\text {prec }}$ is adjusted manually to obtain an optimal fit with the annual in-situ measurements. Table 3 illustrates the RMSE obtained between modelled and measured point values.

Table 3

Root mean square errors (RMSE) for the comparison between the measured and modelled point values for annual mass balances.

\begin{tabular}{ll}
\hline Year & RMSE (m w.e.) \\
\hline 2011 & 0.19 \\
2012 & 0.17 \\
2013 & 0.15 \\
2014 & 0.19 \\
2015 & 0.12 \\
2016 & 0.22 \\
\hline
\end{tabular}

Table 4

Average values of calibrated model parameters, their standard deviations (stdv) and units. $\mathrm{dT} / \mathrm{dz}$ is based on a study by Aizen et al. (1995).

\begin{tabular}{llll}
\hline Parameter & Value & stdv & Units \\
\hline$F_{M}$ & 3.82 & \pm 0.23 & $10^{-3} \mathrm{~m}$ w.e.d $\mathrm{d}^{-1}{ }^{\circ} \mathrm{C}^{-1}$ \\
$r_{\text {snow }}$ & 0.35 & \pm 0.01 & $10^{-5} \mathrm{~m}$ w.e. $\left(W \mathrm{~m}^{-2}\right)^{-1} \quad d^{-1}{ }^{\circ} \mathrm{C}^{-1}$ \\
$r_{\text {ice }}$ & 0.71 & \pm 0.02 & $10^{-5} \mathrm{~m}$ w.e. $\left(W \mathrm{~m}^{-2}\right)^{-1} \mathrm{~d}^{-1}{ }^{\circ} \mathrm{C}^{-1}$ \\
$d T / d z$ & 7.3 & & ${ }^{\circ} \mathrm{C} \mathrm{km}$ \\
$c_{\text {prec_winter }}$ & 1.29 & \pm 0.10 & - \\
$c_{\text {prec_summer }}$ & 1.07 & \pm 0.03 & - \\
\hline
\end{tabular}

2.3. Reconstruction of the glacier-wide mass balance from $2003 / 2004$ to 2009/10

The mass balance model described above is used to reconstruct the mass balance for the period from 2003/04 to 2009/10 for Batysh Sook Glacier, thus for years without glaciological observations. The model parameters ( $c_{\text {prec_winter/summer }}, F_{M}, r_{\text {snow }}$ and $r_{\text {ice }}$ ) are averaged, which have been automatically and partly calibrated manually based on direct glaciological measurements over a period of six years (Table 4). They are held constant in order to model daily mass balances from 2003/04 to $2009 / 10$. $D_{\text {snow }}$ is constrained to the extensive field measurements in May 2014. The temperature lapse rate and the potential clear-sky direct solar radiation are kept unchanged over the entire modelling period.

\subsection{Snow-covered area fraction for model validation}

We use georeferenced Landsat satellite images to map the snowline on Batysh Sook Glacier using ArcGIS 10. The transient snowline on the glacier marks the limit between snow-covered and snow-free area (idem ice surface) on a glacier and is a proxy for the sub seasonal mass balance. From the delineation of the snowline it becomes possible to calculate the snow-covered area fraction (SCAF), which is the glacier area covered by snow in relation to the total area of the glacier at this time. Comparison of the SCAF derived from remotely sensed images with the modelled SCAF for the exact same date enables an independent model validation to be performed (Barandun et al., 2015; Kronenberg et al., 2016). We found a total of 57 Landsat scenes with sufficient visibility for observing SCAFs (Table 1). A drawback to the validation is the limited number of images with good visibility, as is the case in 2005.

The uncertainty related to calculating the SCAF on the Landsat images depends primarily on the snowline delineation. We estimated the snowline delineation uncertainty to be within a range of 7 image pixels (30 m resolution) taking into account the visible transition zone between ice and snow surface on the satellite images. For all satellite images the encountered values ranges from $4 \%$ to $35 \%$ depending of the location of the snowline. The average for all observed SCAFs is $10 \%$. Similar uncertainties $( \pm 11 \%)$ are found by means of a "round robin" exercise for a selected range of Landsat images from 2004 to 2016.

The observed SCAF is in general a bit higher than the modelled fractions (Fig. 5), leading us to expect the modelled mass balance to be somewhat too negative. However, with an RMSE of $14 \%$, including all observation dates, the agreement is satisfactory. A mismatch is observed mainly around fresh snowfall events and a shift in timing (Fig. 6). However, modelled snowfall is reproduced in most cases within \pm 5 days around the actual observed precipitation event (Fig. 7). On 22 satellite images, the glacier was entirely snow-covered (observed $\mathrm{SCAF}=100 \%$ ).

\subsection{Uncertainty analysis}

The error estimates of in-situ measurements of ablation $\left(\sigma_{\text {acc }}\right)$ and accumulation $\left(\sigma_{\mathrm{acc}}\right)$ are adopted from Thibert et al. (2008). 


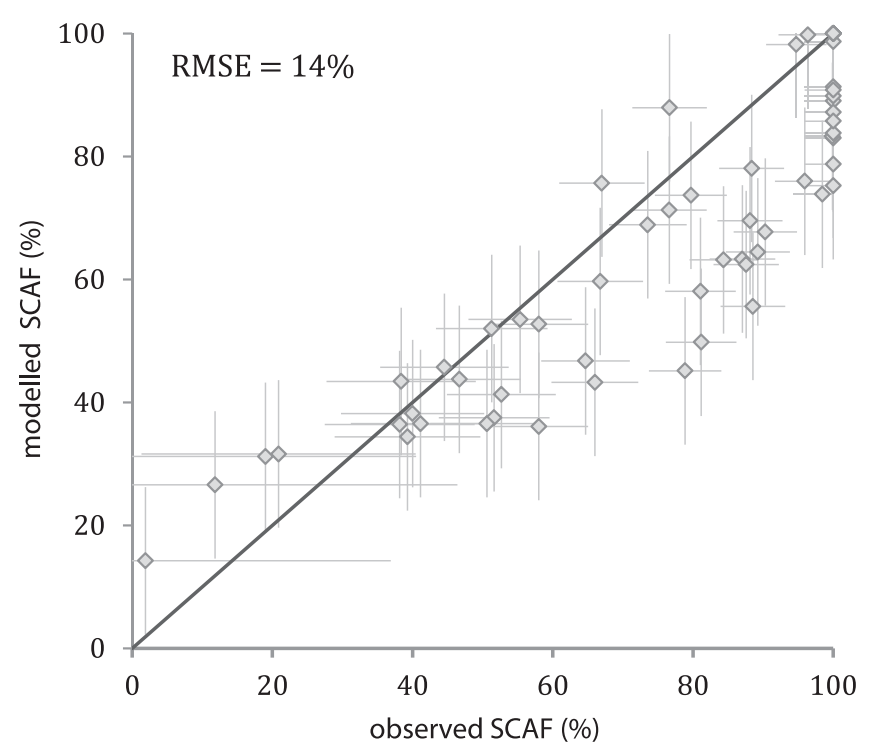

Fig. 5. Observed snow-covered area fraction (SCAF) in comparison to the modelled SCAF for all observation dates. The line indicates a perfect agreement between observed and modelled SCAF, and each diamond represents an actual SCAF observation. The uncertainty for the modelled SCAF is estimated at $\pm 12 \%$, corresponding to an uncertainty in the mass balance of $\pm 0.26 \mathrm{~m}$ w.e. $\mathrm{a}^{-1}$ (e.g. Huss et al., 2013) Uncertainties in the observed SCAF range from \pm 4 to $\pm 35 \%$.

Uncertainties inherent to point observations are related mainly to errors in stake readings, mass conversion, the accuracies of observations of snow depth and density as well as to stratigraphic errors (Thibert et al., 2008).

Uncertainties related to the profile method primarily depend on the representativeness of the point measurements and the linear relation of those measurements with altitude. The main limitation of the method is related to data scarcity in the accumulation area. Here, the uncertainty estimate is composed of: (i) uncertainties in the in-situ measurement (as described above), (ii) the uncertainty related to the extrapolation from point measurements to the entire glacier area in the accumulation zone, and (iii) the uncertainty related to the fit of the linear function in the ablation area.

To assess the uncertainty related to the choice of extrapolation method in the accumulation area $\left(\sigma_{\text {acc } \_ \text {area }}\right)$, we used three different approaches to obtain annual accumulation from point measurements for each year: (1) a constant value (average of all accumulation measurements) is extrapolated to all the elevation bins in the accumulation area, (2) a linear gradient through accumulation measurements, and (3) an inverse gradient for the two uppermost elevation bins is used. The standard deviation from those results is interpreted as the uncertainty related to the extrapolation scheme above the ELA $\left(\sigma_{\text {acc_area }}= \pm 0.18 \mathrm{~m}\right.$ w.e. $\left.\mathrm{a}^{-1}\right)$. The uncertainty related to the extrapolation in the ablation area ( $\left.\sigma_{\text {abl_area }}\right)$ is estimated from the one-sigma confidence intervals of the regression coefficient and leads to a value of $\sigma_{\text {abl_area }}= \pm 0.12 \mathrm{~m}$ w.e. $\mathrm{a}^{-1}$ (e.g., Sold et al., 2016). The combination of these different uncertainties of the profile method results in a total annual uncertainty of $\sigma_{\text {profile }}= \pm 0.28 \mathrm{~m}$ w.e. $\mathrm{a}^{-1}$ (Table 5).

The uncertainty of the contour line method consists of the uncertainty of the point measurements (see above) and the uncertainty related to the extrapolation method. The latter is linked with the subjective interpretation and manual drawing of the contours by the observer (Sold et al., 2016). Here, the respective uncertainty is assessed with using a "round-robin" test. Twelve observers with different level of expertise independently analyzed the point measurements from 2016 using the contour line method. The standard deviation obtained from this experiment is interpreted as the uncertainty of the extrapolation method and it is assumed to be similar for all years. The uncertainty range of the contour line method is the combination of this extrapolation uncertainty and the uncertainty of the point measurements, and results in an average value of $\sigma_{\text {contour }}= \pm 0.20 \mathrm{~m}$ w.e. $\mathrm{a}^{-1}$ (Table 5).

To quantify the uncertainty components of the model-based extrapolation, we performed an analysis following Kronenberg et al. (2016). The uncertainty in the calculated glacier-wide balance ( $\sigma_{\text {glac }}$ for 2010 / $11-15 / 16$ ) is related to the uncertainties of: (i) the in-situ measurements of ablation $\left(\sigma_{\mathrm{abl}}\right)$ and accumulation $\left(\sigma_{\mathrm{acc}}\right)$ (as described above), (ii) the extrapolation from point measurements to the entire glacier surface (model uncertainty $\left(\sigma_{\text {mod }}\right)$ ) and (iii) the extrapolation of the mass balance to the hydrological year $\left(\sigma_{\text {extr }}\right)$. Additionally, (iv) the effect is estimated of the non-adjusted topography $\left(\delta_{\text {topo }}\right)$ and $(v)$ the uncertainty related to the use of the snow distribution multiplier $\left(D_{\text {snow }}\right)$ based on limited snow accumulation measurements $\left(\sigma_{\mathrm{sd}}\right)$. The uncertainty produced by the extrapolation algorithm used in the mass balance model $\left(\sigma_{\text {mod }}\right)$ is assessed by re-running the model for the period 2003/04 to $15 / 16$ with a set of parameters that differ from the calibrated values influencing the extrapolation scheme. We vary the values for $c_{\text {prec_winter/summer }}$ by $\pm 25 \%$ and temperature lapse rate by $\pm 20 \%$. The standard deviation of the annual differences in mass balance obtained from the calibrated and altered parameter sets is then interpreted as
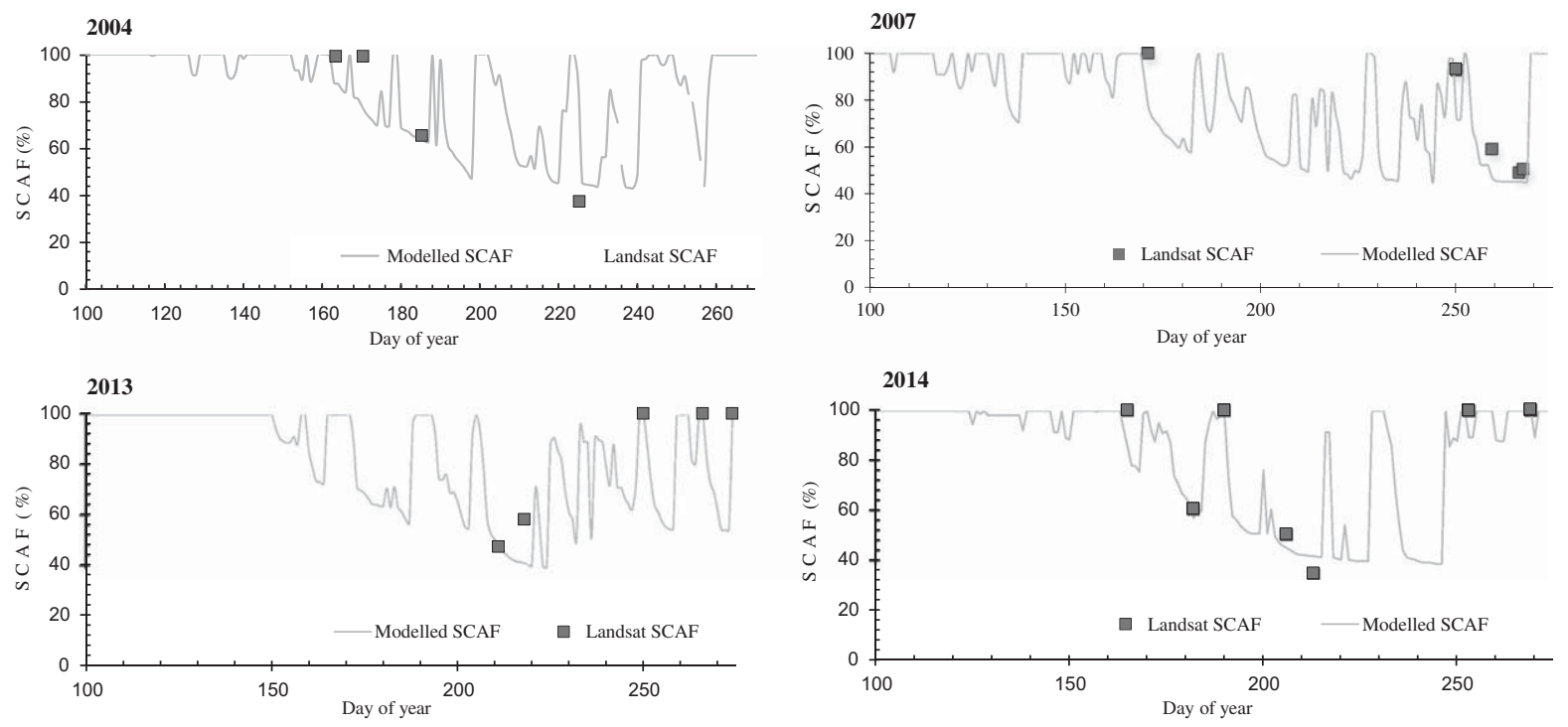

Fig. 6. Validation of modelled daily SCAF throughout the ablation season with the SCAF detected on Landsat imagery for the years 2004,2007 and $2013,2014$. 


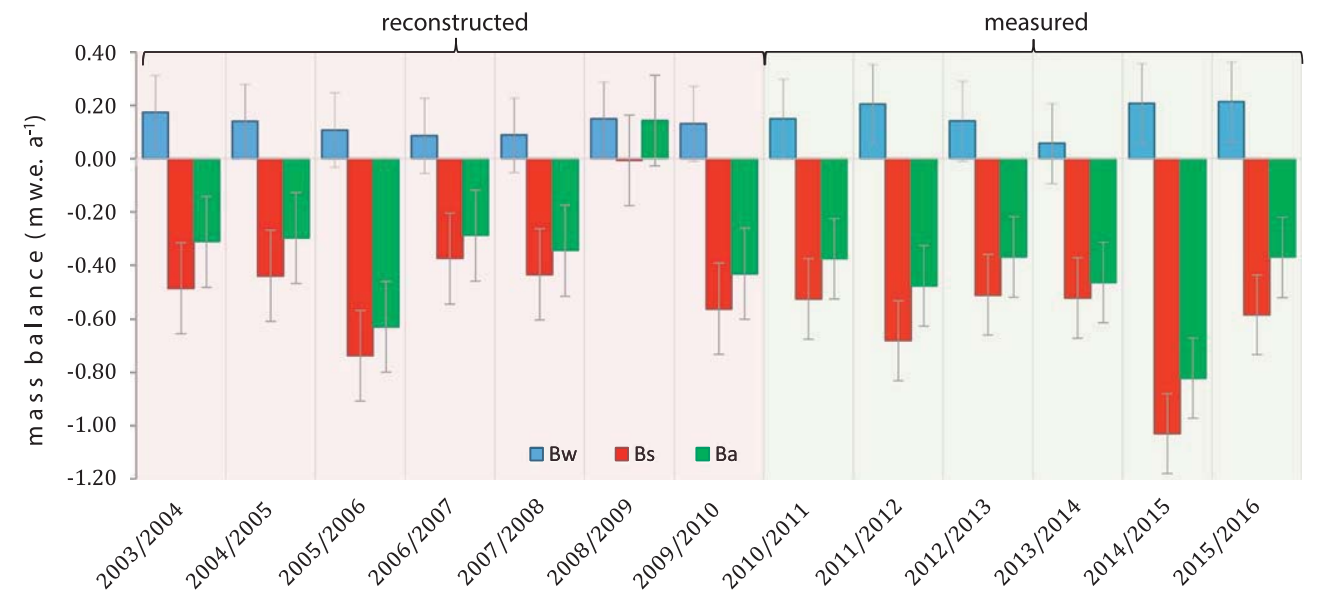

Fig. 7. Reconstructed (2003/04-2009/10) and measured (2010/11-2015/16) summer balance ( $B_{s}$, red), winter balance ( $B_{w}$, blue) and annual mass balance ( $B_{a}$, green). Values from the model based approach are used here.

an estimate for $\sigma_{\text {mod. }}$. To estimate the uncertainty related to the extrapolation of the mass balance from the observation date to the hydrological year $\left(\sigma_{\text {extr }}\right)$, we compare the daily modelled mass balance calibrated to the in-situ measurements from the end of July 2016 to the daily modelled mass balance calibrated with data collected in midSeptember 2016, thus close to the end of the hydrological year. A disagreement of $\sigma_{\text {extr bw }}= \pm 0.04 \mathrm{~m}$ w.e. $\mathrm{a}^{-1}$ was found for the winter balance and of $\sigma_{\text {extr_bn }}= \pm 0.08 \mathrm{~m}$ w.e. $\mathrm{a}^{-1}$ for the annual balance. These values are assumed to be similar from year to year. To test the effect of the unchanged glacier elevation $\left(\sigma_{\text {topo }}\right)$, a sensitivity analysis is performed by adding and subtracting the highest possible elevation change to the SRTM DEM. The highest elevation change for one year is deduced from the highest snow depth and ablation point observation. A maximal possible elevation change of $\pm 25 \mathrm{~m}$ from 2000 to 2016 is estimated based on point measurements. The effect on the measured annual mass balances (2010/11-2015/16) is only $\sigma_{\text {topo }}= \pm 0.001 \mathrm{~m}$ w.e $\mathrm{a}^{-1}$. For the modelled mass balance (2003/04-2009/10) the effect is somewhat higher $\left(\sigma_{\text {topo }}= \pm 0.05 \mathrm{~m}\right.$ w.e. $\left.\mathrm{a}^{-1}\right)$. The snow distribution multiplier $D_{\text {snow }}$ is based on measurements from one field survey only. No information is available on the temporal evolution of the snow depth pattern. To estimate the impact of this effect, the model was re-run with the assumption of a uniform snow distribution with $D_{\text {snow }}(\mathrm{x}, \mathrm{y})=1=$ const. The standard deviation of the differences

\section{Table 5}

Uncertainty analysis of glaciological and reconstructed mass balances. Averages of the uncertainty components are given for the annual and the winter balances. It is indicated for which mass balance year this uncertainty component is considered in order to calculate the total uncertainty of the glaciological $\sigma_{\text {glac }}$ : $(2011-2016)$ and reconstructed $\sigma_{\text {rec }}$ : $(2003-2010)$ mass balances, respectively $\sigma_{a c c}$ and $\sigma_{a b l}$ are the uncertainties from the point measurements, $\sigma_{\text {opt }}$ is the uncertainty due to a missing parameter optimization, $\sigma_{\text {mod }}$ is the model uncertainty, $\sigma_{\text {extr }}$ is the uncertainty related to the extrapolation in time from the last observation of the year to fit the hydrological year, $\sigma_{\text {topo }}$ is the uncertainty due to the non-adjusted surface elevation and $\sigma_{\text {sd }}$ is the uncertainty of the snow distribution. $\sigma_{\text {profile }}$ and $\sigma_{\text {contour }}$ indicate the uncertainty related to the profile and contour line method, respectively.

\begin{tabular}{lllll}
\hline & Annual & Winter & Years & Unit \\
\hline$\sigma_{\text {acc }}$ & \pm 0.09 & \pm 0.09 & $2011-2016$ & $\mathrm{~m} \mathrm{w.e.} \mathrm{a}^{-1}$ \\
$\sigma_{\text {abl }}$ & \pm 0.04 & - & $2011-2016$ & $\mathrm{~m} \mathrm{w.e.} \mathrm{a}^{-1}$ \\
$\sigma_{\text {opt }}$ & \pm 0.30 & \pm 0.01 & $2003-2010$ & $\mathrm{~m}$ w.e. $\mathrm{a}^{-1}$ \\
$\sigma_{\text {mod }}$ & \pm 0.04 & \pm 0.01 & $2003-2016$ & $\mathrm{~m} \mathrm{w.e.} \mathrm{a}^{-1}$ \\
$\sigma_{\text {extr }}$ & \pm 0.08 & \pm 0.04 & $2011-2016$ & $\mathrm{~m} \mathrm{w.e.} \mathrm{a}^{-1}$ \\
$\sigma_{\text {topo }}$ & \pm 0.03 & \pm 0.03 & $2003-2016$ & $\mathrm{~m} \mathrm{w.e.} \mathrm{a}^{-1}$ \\
$\sigma_{\text {sd }}$ & \pm 0.08 & \pm 0.02 & $2003-2016$ & $\mathrm{~m} \mathrm{w.e.} \mathrm{a}^{-1}$ \\
$\sigma_{\text {rec }}$ & \pm 0.34 & \pm 0.11 & $2003-2010$ & $\mathrm{~m} \mathrm{w.e.} \mathrm{a}^{-1}$ \\
$\sigma_{\text {glac }}$ & \pm 0.16 & \pm 0.10 & $2011-2016$ & $\mathrm{~m} \mathrm{w.e.} \mathrm{a}^{-1}$ \\
$\sigma_{\text {profile }}$ & \pm 0.28 & - & $2011-2016$ & $\mathrm{~m} \mathrm{w.e.} \mathrm{a}^{-1}$ \\
$\sigma_{\text {contour }}$ & \pm 0.20 & - & $2011-2016$ & $\mathrm{~m}$ w.e. $\mathrm{a}^{-1}$ \\
\hline
\end{tabular}

between the annual mass balance obtained including the snow distribution pattern from 2014 and using the uniform snow distribution is interpreted as $\sigma_{\text {sd }}$ (Table 5).

For the modelled glacier-wide balance from 2003/04 to 2009/10 an additional uncertainty is introduced due to $(v)$ the missing direct measurements (2003/04 to 2009/10), the missing parameter optimization uncertainty $\left(\sigma_{\mathrm{opt}}\right)$. To quantify $\sigma_{\mathrm{opt}}$, the calibrated model runs for the years $2010 / 11$ to $2015 / 16$ are compared to non-calibrated runs. The standard deviation is interpreted as the uncertainty related to non-optimized mass balance results from 2003/04 to 2009/10. Table 5 summarizes all the calculated uncertainties for the winter and the annual mass balance applying the rules of Gaussian error propagation to combine the different uncertainty components.

\section{Results}

\subsection{Mass balance from $2010 / 11$ to $2015 / 16$}

The annual mass balance measured using the glaciological method (model-based extrapolation) is negative between 2010/11 and 2015/ 16 (Table 6 and Fig. 7). The strongest mass loss is observed for 2014/ 15 due to strongly enhanced ablation during June and July, which is not compensated for by the exceptionally high accumulation during the winter season (Fig. 8). The average summer month (JJA) air temperature 2015 registered at Tien Shan station was $5.7^{\circ} \mathrm{C}$, which is more than one degree higher than average summer air temperature of the preceding years (Fig. 2). These extreme conditions in early summer 2015 with enhanced ablation caused flooding and other natural hazards in many regions of the Tien Shan (personal communication: $\mathrm{R}$. Usubaliev). Almost equally negative mass balances were measured in 2011/12 and 2015/16. However, homogenized to fit the hydrological year, both years show a less negative annual mass balance than the extreme year 2014/15 ( $B_{a}$ (fix) in Table 6). Summer air temperatures measured at the Tien Shan station in 2012 were average, whereas 2016 again showed relatively high air temperatures $\left(5.2{ }^{\circ} \mathrm{C} \mathrm{JJA}\right)$. Nevertheless, annual precipitation was considerably higher in 2015/16 than in the previous extreme year. The year 2013/2014 shows a comparable negative balance which is, by contrast, related to reduced accumulation in winter, not to high summer temperatures (Fig. 8). The year 2010/11 was characterized by close to average conditions with somewhat higher annual precipitation resulting in a slight positive winter balance anomaly (Fig. 8). The balance for the 2010/11 measurement period is less negative than for the other years (model-based analysis), balanced (contour line approach) or even positive (profile method). Here, however, it must be kept in mind that the measurement period in 2010/11 does not span 12 months. If we consider the results 
Table 6

(A) Modelled seasonal mass balance of Batysh Sook Glacier from 2003/04 to 2009/10 with $B_{w}$ the winter balance from 1st of October to 31st of May, $B_{a}$ the mass balance over the hydrological year (fixed period) for the model results. For the years 2010/11 until 2015/16, the mass balances are based directly on the in-situ measurements and given for the measurement period and the hydrological year. Additionally, the mass balance gradient for each year is calculated. (B) Mass balance calculated with the profile line and (C) contour line methods from 2010/11 to 2015/16. Note that $B_{a}$ for the profile and contour line method is the balance that corresponds to the measurement period. The Equilibrium-Line Altitude (ELA) is calculated to the point where zero mass balance is located, and the mass balance gradient ( $\delta \mathrm{b} / \delta \mathrm{z}$ ) represents the gradient found from the lowermost elevation band to the ELA.

\begin{tabular}{|c|c|c|c|c|c|c|c|c|}
\hline \multicolumn{8}{|c|}{ Reconstructed mass balance } & \multirow{2}{*}{$\begin{array}{l}(\mathrm{A}) \\
\delta \mathrm{b} / \delta \mathrm{z} \\
\left(\mathrm{m} \text { w.e } 100 \mathrm{~m}^{-1}\right)\end{array}$} \\
\hline Year & $\begin{array}{l}\text { Area } \\
\left(\mathrm{km}^{2}\right)\end{array}$ & $\begin{array}{l}\text { ELA } \\
\text { (m a.s.l.) }\end{array}$ & $\begin{array}{l}B_{w}\left(m \text { w.e. } a^{-1}\right) \\
\text { Fixed period } \\
\text { (1.Oct.-30.Sep.) }\end{array}$ & $\begin{array}{l}\text { Uncertainty } \\
\left(\mathrm{m} \text { w.e. } \mathrm{a}^{-1}\right)\end{array}$ & $\begin{array}{l}\mathrm{B}_{\mathrm{a}}\left(\mathrm{m} \text { w.e. } \mathrm{a}^{-1}\right) \\
\text { (measured } \\
\text { period) }\end{array}$ & $\begin{array}{l}\text { Uncertainty } \\
\left(\mathrm{m} \text { w.e. } \mathrm{a}^{-1}\right)\end{array}$ & $\begin{array}{l}\mathrm{B}_{\mathrm{a}}\left(\mathrm{m} \text { w.e. } \mathrm{a}^{-1}\right) \\
\text { fixed period } \\
\text { (1.0ct.-30.Sep.) }\end{array}$ & \\
\hline 2003/04 & 1.15 & 4255 & 0.17 & \pm 0.11 & & \pm 0.34 & -0.31 & 0.44 \\
\hline $2004 / 05$ & 1.15 & 4255 & 0.14 & \pm 0.11 & & \pm 0.34 & -0.30 & 0.46 \\
\hline 2005/06 & 1.15 & 4285 & 0.11 & \pm 0.11 & & \pm 0.34 & -0.63 & 0.43 \\
\hline 2006/07 & 1.14 & 4255 & 0.09 & \pm 0.11 & & \pm 0.34 & -0.29 & 0.29 \\
\hline 2007/08 & 1.13 & 4265 & 0.09 & \pm 0.11 & & \pm 0.34 & -0.34 & 0.41 \\
\hline $2008 / 09$ & 1.13 & 4175 & 0.15 & \pm 0.11 & & \pm 0.34 & +0.14 & 0.21 \\
\hline $2009 / 10$ & 1.13 & 4255 & 0.13 & \pm 0.11 & & \pm 0.34 & -0.43 & 0.52 \\
\hline \multirow[t]{2}{*}{ 2004-2010 } & 1.14 & 4249 & 0.13 & $\pm \mathbf{0 . 1 1}$ & & \pm 0.34 & -0.31 & 0.39 \\
\hline & \multicolumn{7}{|c|}{ Mass balance derived by model-based extrapolation } & \\
\hline 2010/11 & 1.13 & 4255 & 0.15 & \pm 0.10 & -0.24 & \pm 0.17 & -0.38 & 0.52 \\
\hline $2011 / 12$ & 1.13 & 4265 & 0.21 & \pm 0.10 & -0.59 & \pm 0.15 & -0.48 & 0.54 \\
\hline $2012 / 13$ & 1.12 & 4255 & 0.14 & \pm 0.10 & -0.42 & \pm 0.16 & -0.37 & 0.46 \\
\hline $2013 / 14$ & 1.11 & 4265 & 0.06 & \pm 0.10 & -0.47 & \pm 0.16 & -0.46 & 0.45 \\
\hline $2014 / 15$ & 1.11 & 4305 & 0.21 & \pm 0.10 & -0.69 & \pm 0.15 & -0.82 & 0.45 \\
\hline $\begin{array}{l}\text { 2015/16 } \\
\text { (6 Aug.-17 Jul.) }\end{array}$ & 1.11 & 4245 & 0.22 & \pm 0.10 & -0.16 & \pm 0.14 & -0.37 & 0.60 \\
\hline $\begin{array}{l}\text { 2015/16 } \\
\text { (6 Aug.-13 Sep.) }\end{array}$ & 1.11 & 4265 & 0.22 & \pm 0.10 & -0.63 & \pm 0.14 & -0.42 & 0.63 \\
\hline 2011-2016 & 1.12 & 4265 & 0.16 & \pm 0.10 & -0.43 & \pm 0.16 & -0.48 & 0.51 \\
\hline \multirow[t]{2}{*}{ 2004-2016 } & 1.13 & 4257 & 0.14 & $\pm \mathbf{0 . 1 1}$ & & \pm 0.26 & -0.39 & 0.45 \\
\hline & \multicolumn{5}{|c|}{ Mass balance derived by profile method } & & & (B) \\
\hline $2010 / 11$ & 1.13 & 4125 & & & +0.13 & \pm 0.28 & & \\
\hline 2011/12 & 1.13 & 4300 & & & -0.73 & \pm 0.28 & & \\
\hline $2012 / 13$ & 1.12 & 4225 & & & -0.29 & \pm 0.28 & & \\
\hline $2013 / 14$ & 1.11 & 4225 & & & -0.45 & \pm 0.28 & & \\
\hline $2014 / 15$ & 1.11 & 4325 & & & -0.59 & \pm 0.28 & & \\
\hline $\begin{array}{l}\text { 2015/16 } \\
\text { (6 Aug.-17 Jul.) }\end{array}$ & 1.11 & 4190 & & & +0.13 & \pm 0.28 & & \\
\hline $\begin{array}{l}\text { 2015/16 } \\
\text { (6 Aug.-13 Sep.) }\end{array}$ & 1.11 & 4250 & & & -0.53 & \pm 0.28 & & \\
\hline \multirow[t]{2}{*}{ 2011-2016 } & 1.12 & 4250 & & & -0.41 & \pm 0.28 & & \\
\hline & \multicolumn{6}{|c|}{ Mass balance derived by contour line method } & & (C) \\
\hline $2010 / 11$ & 1.13 & 4205 & & & -0.06 & \pm 0.20 & & \\
\hline $2011 / 12$ & 1.13 & 4225 & & & -0.35 & \pm 0.20 & & \\
\hline $2012 / 13$ & 1.12 & 4215 & & & -0.28 & \pm 0.20 & & \\
\hline $2013 / 14$ & 1.11 & 4250 & & & -0.37 & \pm 0.20 & & \\
\hline $2014 / 15$ & 1.11 & 4275 & & & -0.47 & \pm 0.20 & & \\
\hline $\begin{array}{l}\text { 2015/16 } \\
\text { (6 Aug.-17 Jul.) }\end{array}$ & 1.11 & 4185 & & & -0.06 & \pm 0.20 & & \\
\hline $\begin{array}{l}\text { 2015/16 } \\
\text { (6 Aug.-13 Sep.) }\end{array}$ & 1.11 & 4245 & & & -0.48 & \pm 0.20 & & \\
\hline 2011-2016 & 1.12 & 4236 & & & -0.34 & \pm 0.20 & & \\
\hline
\end{tabular}

covering the period of the hydrological year, no exceptional balance is found for 2010/11 ( $B_{a}(f i x)$ in Table 6).

\subsection{Mass balance from $2003 / 04$ to $2009 / 10$}

The reconstructed annual mass balances from 2003/04 to 2009/10 are negative except for 2008/09 (Fig. 7). In this year, due to lower air temperatures and a snow cover protecting the ice surface from ablation during a considerable part of the summer months (Kronenberg et al., 2016), ice and snow melt are significantly diminished (Fig. 8). Accumulation is close to the 13-year-mean of the investigation period (Fig. 8). The most negative balance of the reconstructed period is found for 2005/06; a year with low annual precipitation and average summer air temperatures. The combination of both led to a winter balance which is lower than average and increased ablation in summer. The result is a very negative balance at the end of the hydrological year.

\section{Discussion}

\subsection{Mass balance variability}

Overall, the annual mass balance of Batysh Sook is very sensitive to summer air temperatures, typical for continental glaciers. We observed a much higher variability in the summer balance ( $\mathrm{stdv}=0.21 \mathrm{~m}$ w.e.) in comparison to the winter balance ( $\operatorname{stdv}=0.05 \mathrm{~m}$ w.e). The most negative mass balance of the investigation period occurred when summer air temperatures were highest and the only positive mass balance was found in $2008 / 09$ with an average JJA air temperature of $3.2^{\circ} \mathrm{C}$. The air temperature plays a critical role, determining the precipitation phase 


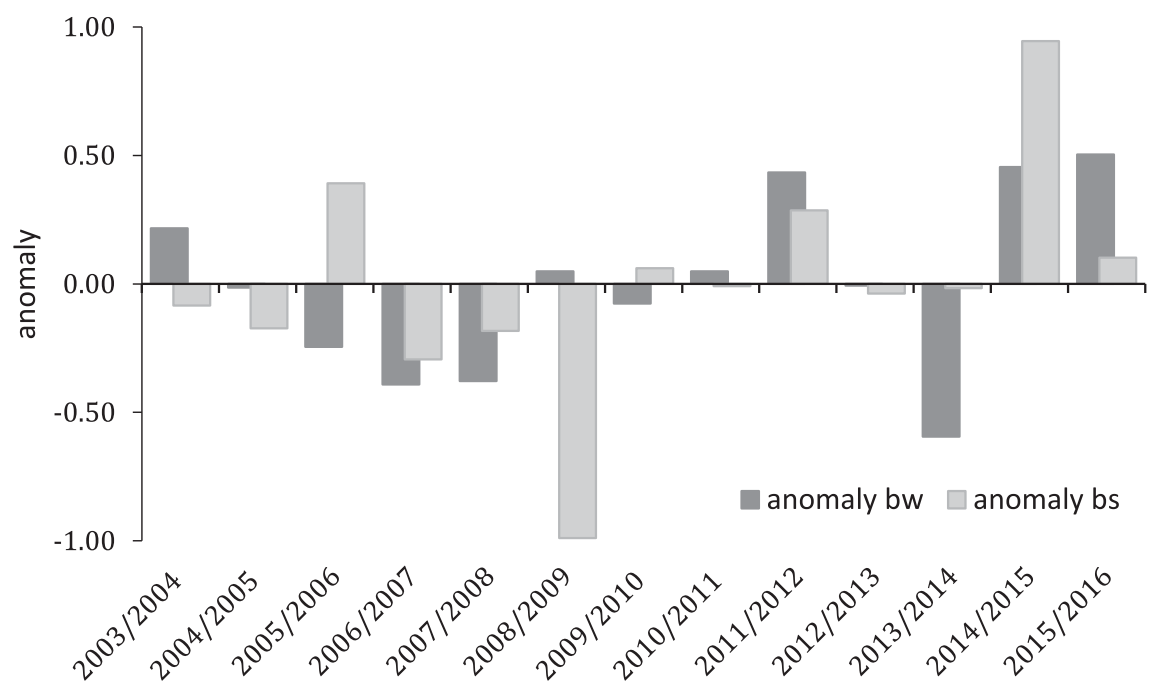

Fig. 8. Mass balance anomalies in comparison to 13-year-mean mass balance (2003 to 2016). Values from the model based approach are used here. For years with below (above) average mass loss during the summer period the summer balance anomaly (bs, light grey bars) is negative (positive). The winter balance anomaly (bw, dark grey bars) is positive (negative) for years with above (below) average winter accumulation.

during the summer months and thereby affects the albedo and the shortwave radiation budget at the glacier surface. The effect of summer accumulation on glaciers in the Inner Tien Shan has been described previously by Dyurgerov et al. (1994) and the importance of summer snow fall events and its consequences on albedo and the short-wave radiation budget are in accordance with findings in nearby regions. In their energy balance study for Chhota Shigri glacier, Western Himalaya, India, Azam et al. (2014a) detected the net shortwave radiation as being the major energy source for ablation. The precipitation intensity and air temperature determining the precipitation phase during the summer-monsoon were most important drivers of mass balance. At decadal scale as well, summer air temperatures were identified an important driving force of mass balance for Chhota Shigri (Azam et al., 2014b). Furthermore, on the Tibetan Plateau an early onset of the summer monsoon precipitation could be associated with reduced ablation mainly through changes in absorbed shortwave radiation (Mölg et al., 2012).

Additionally, for Batysh Sook, a difference in inter-annual mass balance variability depending on elevation can be observed (Fig. 12). The standard deviation and the range of the mass balance within each altitude band show a higher variability in the ablation area
( $\operatorname{stdv}=0.27 \mathrm{~m}$ w.e., range $=1.12 \mathrm{~m}$ w.e. $)$ and a slightly lower one in the accumulation area ( $\mathrm{stdv}=0.20 \mathrm{~m}$ w.e., range $0.82 \mathrm{~m}$ w.e.). We assume that probably the quite simple geometry pattern of the glacier is mainly responsible for such a homogenous accumulation pattern, which is not at all obvious.

\subsection{Comparison of different methods}

The measured mass balances from 2010/11 to 2015/16 are analyzed using conventional methods and a model-based extrapolation. In general, all three methods lead to a similar result illustrating a clear mass loss for the 6 years considered (Table 6 and Fig. 9). The most significant differences between the three methods are found for 2010/11 and 2011/12 (beyond the estimated uncertainties). This discrepancy mirrors the limited data availability for the first years of observation. Over the years the measurement network was improved, leading to more robust results.

The profile method shows its main weaknesses in the uppermost and the lowermost part of the glacier where point measurements are scarcely represented and the mass balance result does not agree with the other two methods (Fig. 10). The glacier does not conform to a strict relation between elevation and mass balance, particularly in the

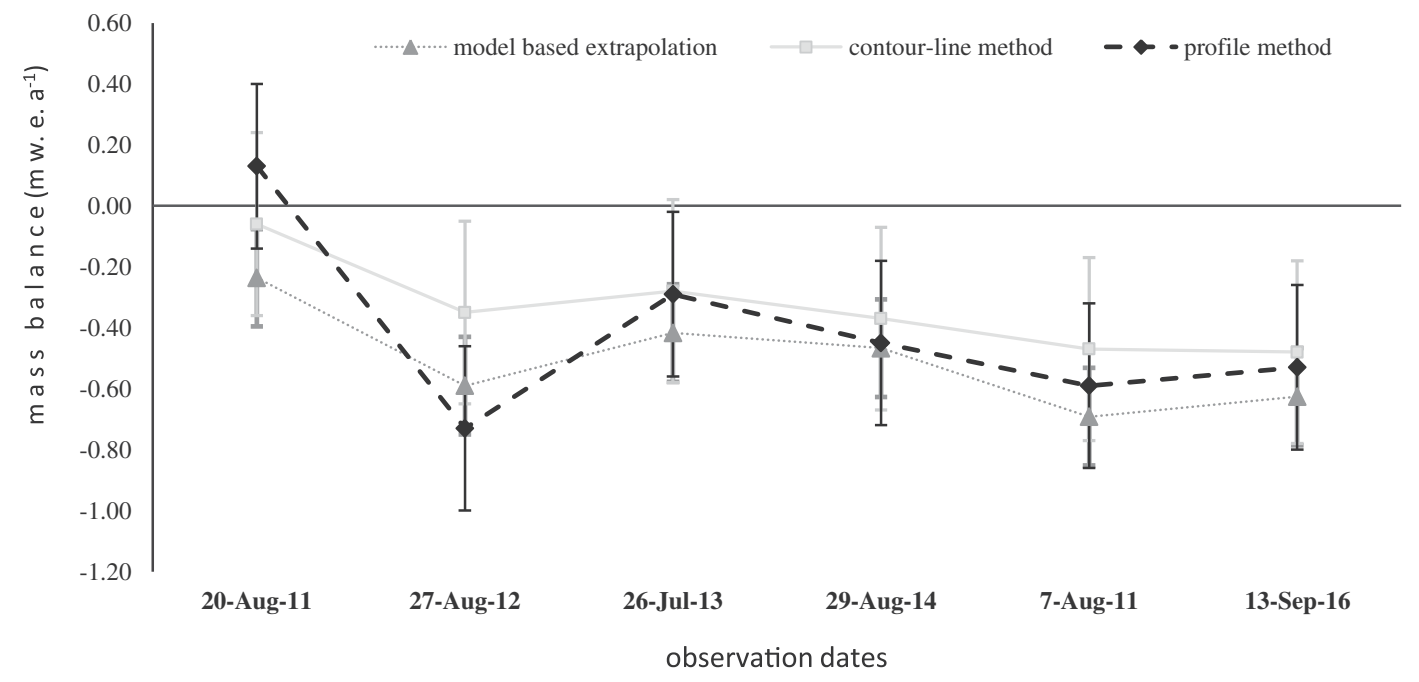

Fig. 9. Comparison of annual mass balance between different methods. 


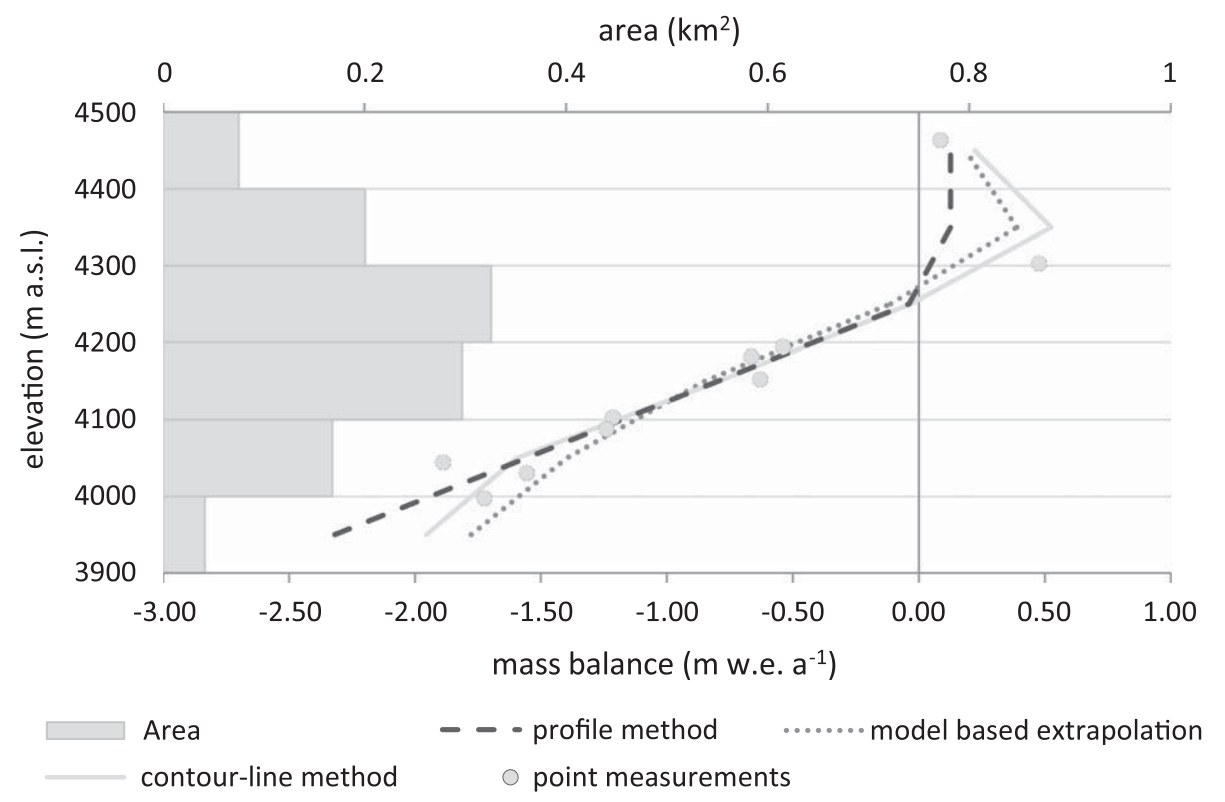

Fig. 10. Elevation dependency of mass balance for the different methods (lines) used to analyze the mass balance of 2013/14. Circles indicate the point measurements. The distribution of the glacier area with elevation is shown with bars.

accumulation area (Fig. 4). Wind drift processes in the uppermost zones as well as avalanche depositions create a more complex mass balance distribution. This pattern cannot be represented appropriately based on the profile method. Nevertheless, the profile method is a simple approach to analyzing point measurements which works satisfactorily well for a rough analysis of mass balance measurements for Batysh Sook.

The contour line method is based on a certain quantity of expertise necessary to draw the isopleths, and in general represents very well the observed spatial melt pattern and snow distribution of a glacier. For Batysh Sook, the mass balance analyzed using the contour line method is generally less negative than the results obtained by the other two methods (Fig. 9). The elevation distribution of the contour line mass balance is similar to the one derived from the model-based extrapolation (Fig. 10). An important advantage of the contour line method is that the net mass balance of a glacier can be calculated independently of altitudinal information.

Due to inaccessibility and logistical difficulties, observation dates vary considerably from year to year, leading to irregular measurements periods. These varying observation periods hamper a sound interpretation. With the model-based approach, the mass balance can be extrapolated to match the hydrological year. The output can then be evaluated between the years and compared to other glaciers. Furthermore, the model is capable of calculating the glacier-wide mass balance on a daily basis, allowing a validation based on transient snowline observations. In addition, the model enables seasonal mass balances to be reconstructed based on meteorological data for years when no direct measurements are available. However, the use of the mass balance model is not a straightforward approach as it depends on additional input data and calibration procedures. Furthermore, this method is much more time-consuming than conventional methods.

Although temporal resolution of the conventional methods is limited to the measurement dates, calculation procedure is easier and neither additional input data nor calibration is needed. We recommend choosing the extrapolation method with a view to the goal of the study and the characteristics of the study site as well as the measurement network. For glaciers where no clear elevation dependency of mass balance is detected, the profile method cannot be considered suitable. Also, if the observation network is limited, the contour line or the model based approach may provide more robust results.
Furthermore, the study shows that for all methods used, large uncertainties are related to the extrapolation of point information in the accumulation area. Despite the highly variable deposition of snow related to redistribution processes by wind or avalanches in this zone, the spatial distribution of the observations is in general limited to accessible parts of the accumulation area. In our study, this is clearly shown in Fig. 10. A good estimate of the accumulation gradient seems to be very difficult because of insufficient data to better constrain the spatial distribution of snow. Several studies (e.g., Sold et al., 2016; Helfricht et al., 2012, 2014) show that an improvement in the mass balance determination is possible through the combination of conventional mass balance data and data obtained by new methods such as helicopter-borne Ground Penetrating Radar or Light Detection And Ranging (LiDAR) measurements. Such data also enables an improvement in the interpolation of the accumulation distribution. Furthermore, accurate digital terrain models can be obtained by complementary methods such as LiDAR, or Structure for Motion and used for geodetic mass balance assessments (e.g. Huss et al., 2008).

Another shortcoming of the methods applied in this study is the fact that they are limited to surface processes. We investigate only the surface mass balance and do not take into account internal accumulation processes. However, on cold and polythermal glaciers, refreezing of meltwater beneath the previous year's summer horizon may contribute to the total mass balance. The only available estimates of internal accumulation in the region date back to $1986-89$ on Sary-Tor Glacier and Gregoriev Ice Cap (Fig. 1) (Dyurgerov and Mikhalenko, 1995). The contribution of internal accumulation (12\%) and superimposed ice (22\%) to net accumulation on Sary-Tor was determined at a value of $34 \%$ (cf. Kronenberg et al. (2016) for more details). Adopting the mean contribution of internal accumulation assessed for Sary-Tor, as a basis, we estimate the superimposed ice and internal accumulation for Bathysh Sook and obtain an insignificant contribution of $<0.005 \mathrm{~m}^{\text {w.e. }} \mathrm{a}^{-1}$ to the glacier-wide mass balance.

Furthermore, in this study sublimation is not individually assessed and neglected. This is an important shortcoming when considering the interpretation of the runoff pattern and quantity. Sublimation processes play an important role in the hydrological balance. However, if we look at the mass changes of the glacier only, the modelled melt factors are calibrated to reproduce the total mass loss, for each point measurement and therefore the parametrization includes both terms of surface mass 
loss, that is, melt and sublimation. If, on the other hand sublimation is important, then we have overestimated melt rates and as a result, the deduced runoff could also be considerably overestimated.

\subsection{Comparison of the mass balance of Batysh Sook Glacier with other gla- ciers in the region}

The mean annual mass balance of $-0.29 \pm 0.34 \mathrm{~m}$ w.e. $\mathrm{a}^{-1}$ from 2003/04 to 2008/09 calculated for Batysh Sook Glacier is somewhat less negative than the result found by Gardner et al. (2013). They estimated a mass balance of $-0.52 \pm 24 \mathrm{~m}$ w.e. $\mathrm{a}^{-1}$ for the entire Tien Shan from 2003 to 2009 based on geodetic measurements. Based on a modelling study, Farinotti et al. (2015) indicated a mass balance of $-0.36 \pm 22 \mathrm{~m}$ w.e. $\mathrm{a}^{-1}$ for the period 1961 to 2012 and a balance of $-0.41 \pm 21 \mathrm{~m}$ w.e. $\mathrm{a}^{-1}$ for the Inner Tien Shan for the period 2003 to 2009. The recent study of Petrakov et al. (2016) also reveals a clear glacier area $(-5.9 \pm 0.34 \%)$ and volume loss $\left(-2.1\right.$ to $\left.-2.5 \mathrm{~km}^{3}\right)$ in the nearby Akshiirak massiv for 2003 to 2013. Overall, these values agree quite well with our mass balance reconstruction for Batysh Sook Glacier.

We compare the results from Batysh Sook Glacier with those from five other glaciers with direct mass balance measurements in the region. Fig. 11 shows the measured and reconstructed annual mass balance of glacier No. 354 (Kronenberg et al., 2016), the measured mass balance of Tuyuksu and Urumqihe No.1 (e.g. WGMS, 2014), reconstructed values for Gregoriev Glacier (Fujita et al., 2011) located in the Tien Shan, and Abramov in the Pamir-Alay (Barandun et al., 2015). For all glaciers, annual mass balances were negative, with the exception of the hydrological year 2008/09, in which a positive or an almost balanced mass budget was found. The nearby located glaciers show a quite similar evolution of the annual mass balances as Batysh Sook for the past decade, whereas Tuyuksu and Abramov glaciers, which are situated further away, show a different behavior, mainly characterized by a more pronounced mass loss. The mass balance calculated for Glacier No. 354 by Kronenberg et al. (2016) indicates a somewhat more negative balance with an annual mass loss of $-0.43 \pm 0.09 \mathrm{~m}$ w.e. $\mathrm{a}^{-1}$ for the period 2003 to 2014. Batysh Sook Glacier is in general slightly less negative $\left(-0.31 \pm 0.28 \mathrm{~m}\right.$ w.e. $\left.\mathrm{a}^{-1}\right)$. Variability of glacier mass balance from one glacier to another on decadal time scales can have manifold controlling factors and are not purely depending on glacier surface area and length characteristics (Rabatel et al., 2016). Batysh Sook Glacier however has a very simple geometry, typical for smaller glaciers. For such glaciers, lower mass turnovers in comparison to larger glaciers with more complex geometry and ice dynamics have been observed in many other mountain ranges (Hoelzle et al., 2003).

Temperature and precipitation are not the only driving forces of glacier mass balance. In fact, the overall mass change is determined mainly by the energy balance at the glacier surface, which is responsible for the direct reaction of the glacier to a certain change in climate. Therefore, the different reactions of glaciers in close vicinity are often related to other influencing factors such as: a) their different hypsometry (Kuhn et al., 1985), b) the influence of changing shortwave net radiation, which is controlled by the diverse characteristics of the albedo related to dirt or debris materials on the glacier surface, and varying fresh snowfalls during the summer months (Fujita and Ageta, 2000; Fujita, 2008a, 2008b; Li et al., 2011; Naegeli et al., 2015), or c) a strong increase in the freezing level as discussed for Urumqihe Glacier No. 1 by Wang et al. (2014).

\subsection{Mass balance gradients}

The mean mass balance gradient found for Batysh Sook is $\delta \mathrm{b} / \delta \mathrm{z}=$ $0.45 \mathrm{~m}$ w.e. $(100 \mathrm{~m})^{-1}$ (2004 to 2016 ) indicates the continentality of the glacier. Mass balance gradients differ strongly from region to region and depend on local climatic conditions and particularly on accumulation amounts and seasonality (Kuhn, 1984). Topographic factors such as exposure, slope and shadowing can have additional effects (Oerlemans and Hoogendoorn, 1989). Kronenberg et al. (2016) found a somewhat higher $\delta b / \delta z\left(0.68 \mathrm{~m}\right.$ w.e. $\left.(100 \mathrm{~m})^{-1}\right)$ for Glacier No. 354 located nearby from 2004 to 2014. This rather high value for a glacier in such a dry and continental region is explained by the sensitivity of the mass balance gradient to summer accumulation, altering the surface type in the ablation area and as a result, the melt pattern (Kronenberg et al., 2016). Glacier No. 354, has a much more complex geometry and exposure. Batysh Sook, by contrast, has a very simple and homogenous hypsometry. Former studies indicate lower values for two glaciers in the Akshiirak range. That is a $\delta b / \delta z$ of $0.3 \mathrm{~m}$ w.e. $(100 \mathrm{~m})^{-1}$ for Davydov Glacier (Fig. 1) from 1983 to 1995 (Aizen and Zakharov, 1989), and for

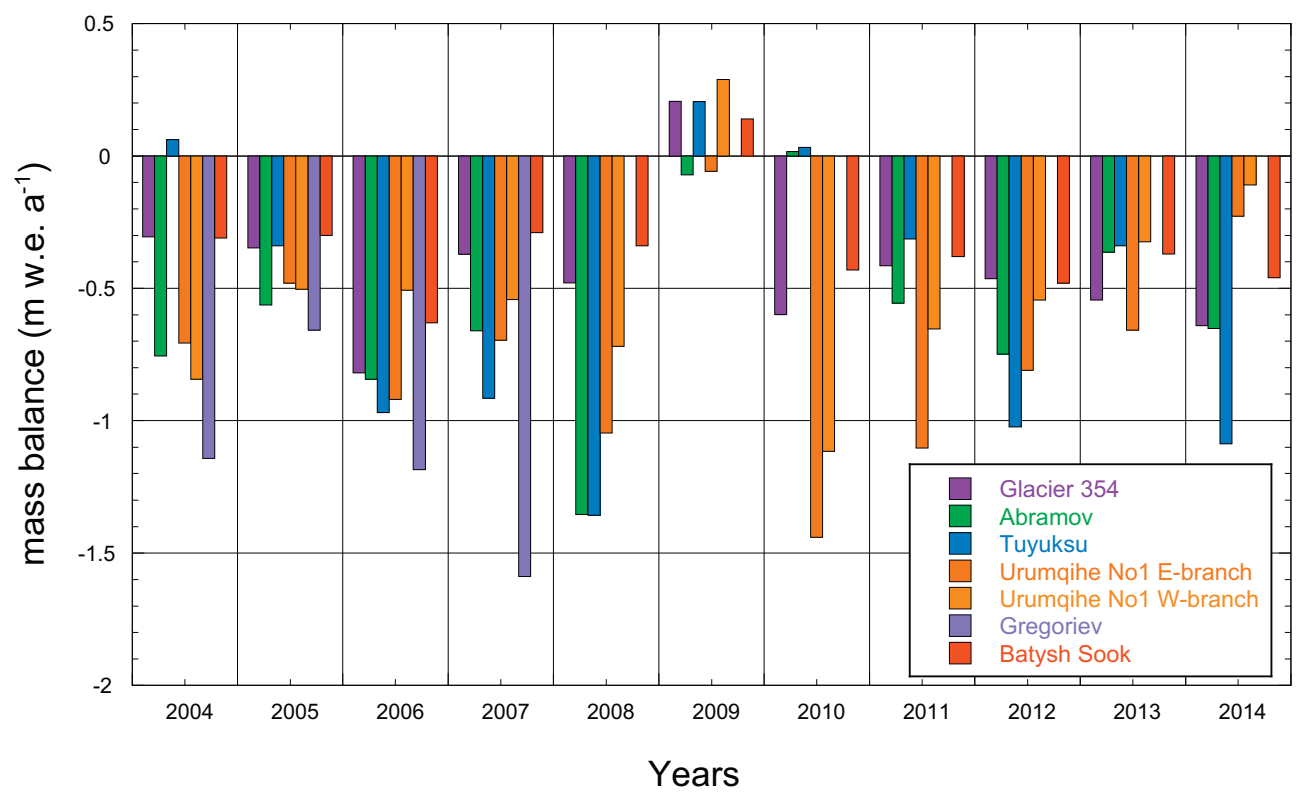

Fig. 11. Comparison of different mass balance values from reconstructed (Gregoriev), reconstructed and measured (Glacier No. 354 and Abramov) and measured (Tuyuksu and Urumqihe Glacier No. 1) series for glaciers in Central Asia. Values refer to the observation period 2003/04 to 2013/14. Mass balance data sources: World Glacier Monitoring Service (WGMS, 2014 for measured data, Kronenberg et al. (2016) for No. 354, Fujita et al. (2011) for Gregoriev and Barandun et al. (2015) for Abramov Glacier. 


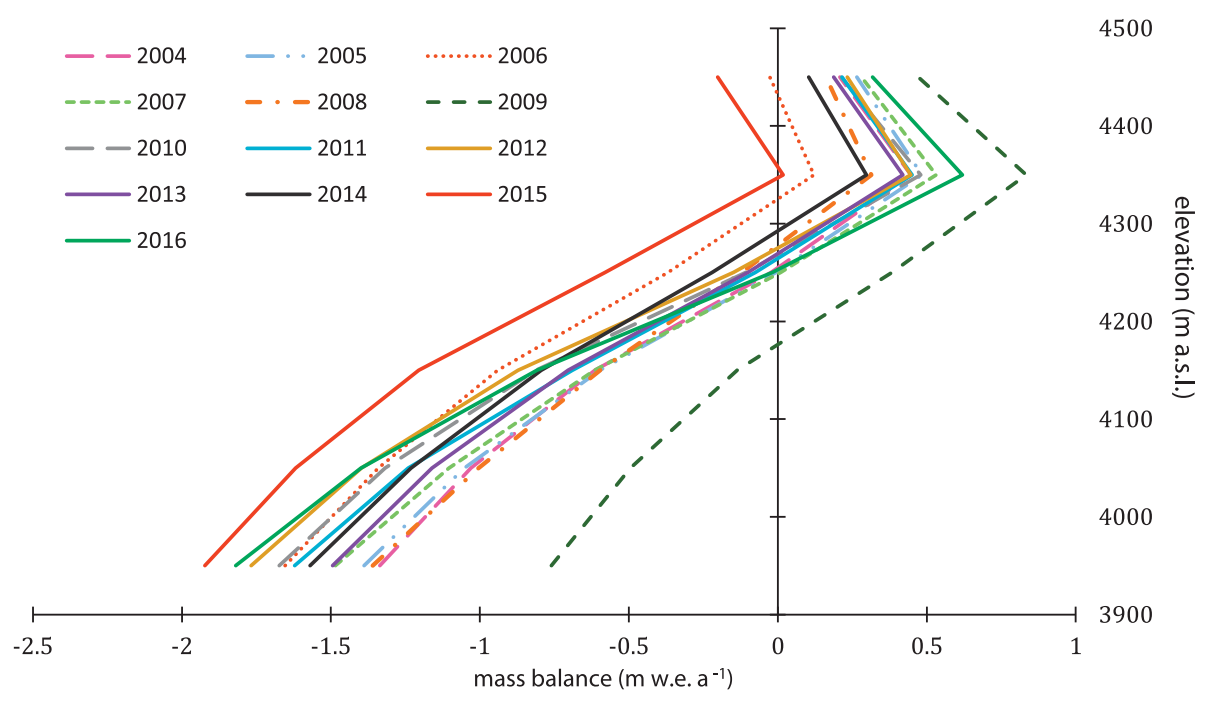

Fig. 12. Comparison of different modelled mass balance gradients with elevation of Batysh Sook Glacier from 2003/04 to 2015/16.

Sary-Tor, a $\delta b / \delta z$ of $0.4 \mathrm{~m}$ w.e. $(100 \mathrm{~m})^{-1}$ from 1985 to 1989 (Ushnurtsev, 1991) were recorded.

An aspect discussed in the literature (e.g. Dyurgerov and Dwyer, 2001; Dyurgerov, 2003; Oerlemans and Hoogendoorn, 1989) which has to be taken into account is a change in the mass balance gradient related to climate change effects. In a warmer climate, many glaciers will show an increase in accumulation and at the same time an increase in ablation (Dyurgerov and Dwyer, 2001). We investigated this effect also at Batysh Sook Glacier (Figs. 7 and 12), but could not detect any trend at this time. However, the 2015/16 mass balance year shows a strongly increased winter accumulation (Fig. 8) and a more negative annual balance. A much steeper gradient of $0.60 \mathrm{~m}$ w.e. $(100 \mathrm{~m})^{-1}$ than the mean found for the period 2004 to $2016\left(0.45 \mathrm{~m}\right.$ w.e $\left.(100 \mathrm{~m})^{-1}\right)$ is the result. Such mass balance gradient changes are quite typical for summer accumulation-type glaciers such as Batysh Sook. If such alterations occur over longer time periods, with a concurrent rise in ablation, the activity index increases and the glacier dynamics can change (Dyurgerov et al., 1994; Meier, 1965; Meier et al., 2003; Oerlemans, 2001; Klok and Oerlemans, 2003; Haeberli et al., 2002). However, only by conducting sound measurements in the near future such changes can be recognized.

\section{Conclusions}

The aim of this study was to determine the subseasonal glacier-wide mass balance for Batysh Sook Glacier between 2003/04 and 2015/16. The study was based on annual glaciological measurements between $2010 / 11$ and $2015 / 16$. The mass balances for $2003 / 04$ to 2009/10 were reconstructed by the application of the calibrated mass balance model. The model output shows a good agreement with observations from Landsat imagery of the snow-covered area fraction throughout the melting season. Batysh Sook Glacier had a mean annual mass balance of $-0.39 \pm 26 \mathrm{~m}$ w.e. $\mathrm{a}^{-1}$ from $2003 / 04$ to $2015 / 16$. For the measurement period from 2010/11 to 2015/16, mean annual mass balance spatially extrapolated with the mass balance model was $-0.48 \pm 0.16 \mathrm{~m}$ w.e. $\mathrm{a}^{-1}$. A similar mass loss of $-0.41 \pm 28 \mathrm{~m}$ w.e. $\mathrm{a}^{-1}$ was found by applying the profile method for the same period. Application of the contour line method resulted in a slightly less negative balance of $-0.34 \pm 20 \mathrm{~m}$ w.e. $\mathrm{a}^{-1}$. Among the conventional approaches, we identified the contour line method as more suitable. The reconstructed cumulative mass balance is in agreement with several remote sensing studies, which report an overall mass loss for glaciers in the Inner Tien Shan, and thus delivers support for the indicated imbalance of glaciers in the region. The reconstructed data series provides information with a high temporal resolution on glacier mass balance for a data-sparse region. This study is a further step toward increasing the understanding of glacier response to climate change in the region and provides a further basis for runoff studies.

\section{Acknowledgements}

The research was supported by the National Natural Science Foundation of China (41630859) and the Program of the State Key Laboratory of Desert and Oasis Ecology, Xinjiang Institute of Ecology and Geography, Chinese Academy of Sciences (Y371163). The study was possible only through the assistance received from the Federal Office of Meteorology and Climatology MeteoSwiss through the Capacity Building and Twinning for Climate Observing Systems (CATCOS) project Phases 1 \& 2, Contract nos. 7F - 08114.1, 455-7F - 08114.02.01, between the Swiss Agency for Development and Cooperation (SDC) and MeteoSwiss. This study received funding from the Swiss National Science Foundation (SNSF), Grant 200021155903. In addition, we extend our gratitude for assistance received from the Central Asian Institute for Applied Geosciences (CAIAG) especially to B. Moldobekov for his continued support of this long-term project and the Central Asian Water project (CAWa) led by the GFZ Potsdam. We also extend thanks to all the helpers and eager field assistants for their efforts, and acknowledge Matthias Huss for providing the mass balance model, and for his support.

\section{References}

Aizen, V., Zakharov, V., 1989. Mass balance and ice flow velocity of Davydov glacier basing on research in 1984-1985. Data Glaciol. Stud. 67, 197-202.

Aizen, V.B., Aizen, E.M., Melack, J.M., 1995. Climate, snow cover, glaciers, and runoff in the Tien Shan. Central Asia. Water Resour. Bull. 31, 1113-1129.

Aizen, V.B., Kuzmichenok, V.A., Surazakov, A.B., Aizen, E.M., 2006. Glacier changes in central and northern Tien Shan during the last 140 years based on surface and remote sensing data. Ann. Glaciol. 43:202-213. http://dx.doi.org/10.3189/ 172756406781812465.

Azam, M.F., Wagnon, P., Vincent, C., Ramanathan, A.L., Linda, A., Singh, V.B., 2014a. Reconstruction of the annual mass balance of Chhota Shigri glacier (western Himalaya, India) since 1969. Ann. Glaciol. 55 (66):69-80. http://dx.doi.org/10.3189/ 2014AoG66A104.

Azam, M.F., et al., 2014b. Processes governing the mass balance of Chhota Shigri Glacier (western Himalaya, India) assessed by point-scale surface energy balance measurements. Cryosphere 8:2195-2217. http://dx.doi.org/10.5194/tc-8-2195-2014.

Barandun, M., Huss, H., Sold, L., Farinotti, D., Azisov, E., Salzmann, N., Usulbaliev, R. Merkushkin, A., Hoelzle, M., 2015. Re-analysis of seasonal mass balance at Abramov glacier 1968-2014. J. Glaciol. 61 (230), 1103-1117.

Bolch, T., 2007. Climate change and glacier retreat in northern Tien Shan (Kazakhstan/ Kyrgyzstan) using remote sensing data. Glob. Planet. Chang. 56, 1-12. 
Chen, Y., Li, W., Deng, H., Fang, G., Li, Z., 2016. Changes in central Asia's Water Tower: Past, Present and Future. Sci. Report. 6, 35458.

Dyurgerov, M., 2003. Mountain and subpolar glaciers show an increase in sensitivity to the climate warming and intensification of the water cycle. J. Hydrol. 282, $164-176$.

Dyurgerov, M.B., Dwyer, J.D., 2001. The steepening of glacier mass balance gradients with northern hemisphere warming. Z. Gletscherk. Glazialgeol. 36, 107-118.

Dyurgerov, M.B., Mikhalenko, V.N. (Eds.), 1995. Oledeneniye Tien Shanya (Glaciation of Tien Shan). VINITI, Moscow.

Dyurgerov, M.B., Mikhalenko, V.N., Kunakhovitch, M.G., Ushnurtsev, S.N., Liu, C., Xie, Z 1994. On the cause of glacier mass balance variations in the Tien Shan mountains. GeoJournal 33 (2-3):311-317. http://dx.doi.org/10.1007/BF00812879.

Escher-Vetter, H., Kuhn, M., Weber, M., 2009. Four decades of winter mass balance of Vernagtferner and Hintereisferner, Austria: methodology and results. Ann. Glaciol. 50, 87-95.

Farinotti, D., Magnusson, J., Huss, M., Bauder, A., 2010. Snow accumulation distribution inferred from time-lapse photography and simple modelling. Hydrol. Process. 24, 2087-2097.

Farinotti, D., Longuevergne, L., Moholdt, G., Duethmann, D., Mölg. T., Bolch, T., Vorogushyn, S., Güntner, A., 2015. Substantial glacier mass loss in the Tien Shan over the past 50 years. Nat. Geosci. 8:716-722. http://dx.doi.org/10.1038/ngeo2513.

Fujita, K., 2008a. Effect of precipitation seasonality on climatic sensitivity of glacier mass balance. Earth Planet. Sci. Lett. 276 (1-2), 14-19.

Fujita, K., 2008b. Influence of precipitation seasonality on glacier mass balance and its sensitivity to climate change. Ann. Glaciol. 48, 88-92.

Fujita, K., Ageta, Y., 2000. Effect of summer accumulation on glacier mass balance on the Tibetan Plateau revealed by mass-balance model. J. Glaciol. 46 (153), 244-252.

Fujita, K., Takeuchi, N., Nikitin, S., Surazakov, A., Okamoto, S., Aizen, V., Kubota, J., 2011. Favourable climatic regime for maintaining the present-day geometry of the Gregoriev Glacier, Inner Tien Shan. Cryosphere 5, 539-549.

Gardner, A.S., Moholdt, G., Cogley, J.G., Wouters, B., Arendt, A.A., Wahr, J., Berthier, E., Hock, R., Pfeffer, W.T., Kaser, G., Ligtenberg, S.R.M., Bolch, T., Sharp, M.J., Hagen, J.O. van den Broeke, M.R., Paul, F., 2013. A reconciled estimate of glacier contributions to sea level rise: 2003 to 2009. Science 340, 852-857.

Haeberli, W., Maisch, M., Paul, F., 2002. Mountain glaciers in global climate-related observation networks. World Meteorol. Org. Bull. 51 (1), 1-8.

Hagg, W., Braun, L., Kuhn, M., Nesgaard, T., 2007. Modelling of hydrological response to climate change in glacierized Central Asian catchments. J. Hydrol. 332, 40-53.

Hagg, W., Mayer, C., Lambrecht, A., Kriegel, D., Azizov, E., 2013. Glacier changes in the Big Naryn basin, Central Tien Shan. Glob. Planet. Chang. 110, 40-50.

Helfricht, K., Schöber, J., Seiser, B., Fischer, A., Stötter, J., Kuhn, M., 2012. Snow accumulation of a high alpine catchment derived from LiDAR measurements. Adv. Geosci. 32, 31-39.

Helfricht, K., Kuhn, M., Keuschnig, M., Heilig, A., 2014. Lidar snow cover studies on glaciers in the Otztal Alps (Austria): comparison with snow depths calculated from GPR measurements. Cryosphere 8 (1), 41-57.

Hock, R., 1999. A distributed temperature-index ice- and snowmelt model including potential direct solar radiation. J. Glaciol. 45 (149), 101-111.

Hoelzle, M., Haeberli, W., Dischl, M., Peschke, W., 2003. Secular glacier mass balances derived from cumulative glacier length changes. Glob. Planet. Chang. 36 (4), 295-306.

Huss, M., Bauder, A., Funk, M., Hock, R., 2008. Determination of the seasonal mass balance of four Alpine glaciers since 1865. J. Geophys. Res. 113 (F1):2156-2202, F01015. http://dx.doi.org/10.1029/2007JF000803.

Huss, M., Bauder, A., Funk, M., 2009. Homogenization of longterm mass-balance time series. Ann. Glaciol. 50:198-206. http://dx.doi.org/10.3189/172756409787769627.

Huss, M., Sold, L., Hoelzle, M., Stokvis, M., Salzmann, N., Farinotti, D., Zemp, M., 2013. Towards remote monitoring of sub-seasonal glacier mass balance. Ann. Glaciol. 54 (63), 85-93

Immerzeel, W.W., van Beek, L.P.H., Bierkens, M.F.P., 2010. Climate change will affect the Asian water towers. Science 328 (1382). http://dx.doi.org/10.1126/science. 1183188.

Jing, Z., Jiao, K., Yao, T., Wang, N., Li, Z., 2006. Mass balance and recession of Ürümqi glacier No. 1, Tien Shan, China, over the last 45 years. Ann. Glaciol. 43, 214-217.

Kaser, G., Fountain, A., Jansson, P., 2003. A manual for monitoring the mass balance of mountain glaciers. Int. Hydrol. Program. 59 (Paris).

Kaser, G., Großhauser, M., Marzeion, B., 2010. Contribution potential of glaciers to water availability in different climate regimes. Proc. Natl. Acad. Sci. 107, 20223-20227.

Khromova, T., Dyurgerov, M., Barry, R., 2003. Late-twentieth century changes in glacier extent in the Ak-shirak range, Central Asia, determined from historical data and ASTER imagery. Geophys. Res. Lett. 30.

Klok, E.J., Oerlemans, J., 2003. Model study of the spatial distribution of the energy and mass balance of Morteratschgletscher, Switzerland. J. Glaciol. 48 (163), 505-518.

Kriegel, D., Mayer, C., Hagg, W., Vorogushyn, S., Duethmann, D., Gafurov, A., Farinotti, D., 2013. Changes in glacierisation, climate and runoff in the second half of the 20th century in the Naryn basin, Central Asia. Glob. Planet. Chang. 110, 51-61.

Kronenberg, M., Barandun, M., Hoelzle, M., Huss, M., Farinotti, D., Azisov, E., Usubaliev, R. Gafurov, A., Petrakov, D., Kaeaeb, A., 2016. Mass balance reconstruction for Glacier No. 354, Tien Shan, from 2003 to 2014. Ann. Glaciol. 57 (71), 92-102.

Kuhn, M., 1984. Mass budget imbalances as criterion for a climatic classification of glaciers. Geogr. Ann. Ser. A. Phys. Geogr. 229-238.

Kuhn, M., Markl, G., Kaser, G., Nickus, U., Obleitner, F., 1985. Fluctuations of climate and mass balance: different responses of two adjacent glaciers. Z. Gletscherk. Glazialgeol. 21, 409-416.
Kutuzov, S., Shahgedanova, M., 2009. Glacier retreat and climatic variability in the eastern Terskey-Alatoo, inner Tien Shan between the middle of the 19 th century and beginning of the 21 st century. Glob. Planet. Chang. 69, $59-70$.

Li, B., Zhu, A., Zhang, Y., Pei, T., Qin, C., Zhou, C., 2006. Glacier change over the past four decades in the middle Chinese Tien Shan. J. Glaciol. 52, 425-432.

Li, Z.Q., Li, H.L., Chen, Y.N., 2011. Mechanisms and simulation of accelerated shrinkage of continental glaciers: a case study of Urumqi Glacier No. 1 in eastern Tianshan, Central Asia. J. Earth Sci. 22 (4):423-430. http://dx.doi.org/10.1007/ s12583-011-0194-5.

Lutz, A.F., Immerzeel, W.W., Gobiet, A., Pellicciotti, F., Bierkens, M.F.P., 2013. Comparison of climate change signals in CMIP3 and CMIP5 multi-model ensembles and implications for Central Asian glaciers. Hydrol. Earth Syst. Sci. 17:3661-3677. http://dx.doi. org/10.5194/hess-17-3661-2013.

Mamatov, N.E., Cusupov, M.K., Raimcanov, B., 2004. Water Resources Problems in Kyrgyzstan. PHD-Thesis, Department of Environmental Engineering. Kyrgyz -Turkish University of Manas, Bishkek, Kyrgyzstan.

Meier, M.F., 1965. Glaciers and Climate. The Quaternary of the United States. Wright HE and Frey DG. Princeton University Press, Princeton, pp. 795-805.

Meier, M.F., Dyurgerov, M.B., McCabe, G.J., 2003. The health of glaciers recent changes in glacier regime. Clim. Chang. 9 (1), 39-44.

Mölg, T., Maussion, F., Yang, W., Scherer, D., 2012. The footprint of Asian monsoon dynamics in the mass and energy balance of a Tibetan glacier. Cryosphere 6:1445-1461. http://dx.doi.org/10.5194/tc-6-1445-2012.

Naegeli, K., Damm, A., Huss, M., Schaepman, M., Hoelzle, M., 2015. Imaging spectroscopy to assess the composition of ice surface materials and their impact on glacier mass balance. Remote Sens. Environ. 168, 388-402.

Narama, C., Kääb, A., Duishonakunov, M., Abdrakhmatov, K., 2010. Spatial variability of recent glacier area changes in the Tien Shan Mountains, Central Asia, using Corona ( 1970 ), Landsat ( 2000), and ALOS ( 2007) satellite data. Glob. Planet. Chang. 71, $42-54$.

Oerlemans, J., 2001. Glaciers and Climate Change. Lisse, A. A. Balkema Publishers.

Oerlemans, J., Hoogendoorn, N.C., 1989. Mass-balance gradients and climatic change. J. Glaciol. 35 (121), 399-405.

Ostrem, G., Brugman, M., 1991. Glacier Mass Balance Measurements: A Manual for Field and Office Work. Sci. Rept Vol. 4. Natl Hydrol. Res. Inst. Envir, Canada. Saskatoon.

Ozmonov, A., Bolch, T., Xi, C., Wei, J., Kurban, A., 2013. Glacier characteristics and changes in the Sary-Jaz river Basin (Central Tien Shan) 1990-2010. Remote Sens. Lett. 4 (8): 725-734. http://dx.doi.org/10.1080/2150704X.2013.789146.

Petrakov, D., Shpuntova, A., Aleinikov, A., Kääb, A., Kutuzov, S., Lavrentiev, I., Usubaliev, R., 2016. Accelerated glacier shrinkage in the Ak-Shyirak massif, Inner Tien Shan, during 2003-2013. Sci. Total Environ. 562, 364-378.

Pieczonka, T., Bolch, T., 2015. Region-wide glacier mass budgets and area changes for the Central Tien Shan between 1975 and 1999 using Hexagon KH-9 imagery. Glob. Planet. Chang. 128, 1-13.

Pieczonka, T., Bolch, T., Wei, J., Liu, S., 2013. Heterogeneous mass loss of glaciers in the Aksu-Tarim Catchment (Central Tien Shan) revealed by 1976 KH-9 Hexagon and 2009 SPOT-5 stereo imagery. Remote Sens. Environ. 130, 233-244.

Rabatel, A., Dedieu, J.P., Vincent, C., 2016. Spatio-temporal changes in glacier-wide mass balance quantified by optical remote sensing on 30 glaciers in the French Alps for the period 1983-2014. J. Glaciol. 62 (236), 1153-1166.

Sold, L., Huss, M., Machguth, H., Joerg, P.C., Leysinger Vieli, G., Linsbauer, A., Salzmann, N., Zemp, M., Hoelzle, M., 2016. Mass balance re-analysis of Findelengletscher, Switzerland; benefits of extensive snow accumulation measurements. Front. Earth SciCryospheric Sci. 18.

Sorg, A., Bolch, T., Stoffel, M., Solomina, O., Beniston, M., 2012. Climate change impacts on glaciers and runoff in central Asia. Nat. Clim. Chang. 2:725-731. http://dx.doi.org/10. 1038/nclimate1592.

Sorg, A., Huss, M., Rohrer, M., Stoffel, M., 2014. The days of plenty might soon be over in glacierized central Asian catchments. Environ. Res. Lett. 9 (10):104. http://dx.doi.org/ 10.1088/1748-9326/9/10/104018 (018).

Tarboton, D., Chowdhury, T., Jackson, T., 1995. A spatially distributed energy balance snowmelt model. In: Tonnessen, K., Williams, M., Tranter, M. (Eds.), Biogeochemistry of Seasonally Snow-Covered Catchments: Proceedings of a Boulder Symposium. IAHS, Boulder, CO, pp. 141-155.

Thibert, E., Blanc, R., Vincent, C., Eckert, N., 2008. Glaciological and volumetric mass-balance measurements: error analysis over 51 years for Glacier de Sarennes. French Alps. J. Glaciol. 54, 522-532.

Unger-Shayesteh, K., Vorogushyn, S., Farinotti, D., Gafurov, A., Duethmann, D., Mandychev, A., Merz, B., 2013. What do we know about past changes in the water cycle of Central Asian headwaters? A review. Glob. Planet. Chang. 110, $4-25$.

Ushnurtsev, S.N., 1991. Experimental Studies of Glacier Regime in Inner Tien Shan for Calculations and Monitoring of Mass Balance and Runoff. PhD thesis. Institute of Geography, Russian, Academy of Sciences Moscow (in Russian).

Vilesov, E.N., Uvarov, V.N., 2001. Evoljutsija sovremennogo oledeninja Zailijskogo Alatau v XX Veke. Kazakh State University, Almaty (in Russian).

Wang, S.M., Zhang, N.C., Pepin, Z., Li, M., Sun, X., Huang, Wang, 2014. Recent changes in freezing level heights in High Asia and their impact on glacier changes. J. Geophys. Res. 119, 1753-1765.

World Glacier Monitoring Service (WGMS), 1998. In: Haeberli, W., Hoelzle, M., Suter, S., Frauenfelder, R. (Eds.), Fluctuations of Glaciers 1990-1995 with addendas From earlier years (Vol. VII). IAHS/UNEP/UNESCO, World Glacier Monitoring Service, Zurich. 
World Glacier Monitoring Service (WGMS), 2012. In: Zemp, M., et al (Eds.), Fluctuations of Glaciers 2005-2010 Vol. IX. ICSU (WDS)/IUGG (IACS)/UNEP/UNESCO/WMO World Glacier Monitoring Service, Zurich, p. 336.

World Glacier Monitoring Service (WGMS), 2014. Fluctuations of Glaciers Database. World Glacier Monitoring Service Zurich http://dx.doi.org/10.5904/wgms-fog-201409.

Wu, Y., He, J., Guo, Z., Chen, A., 2014. Limitations in identifying the equilibrium-line altitude from the optical remote-sensing derived snowline in the Tien Shan, China J. Glaciol. 60 (224):1093-1099. http://dx.doi.org/10.3189/2014JoG13J221.
Zemp, M. Frey, H., Gärtner-Roer, I., Nussbaumer, S.U., Hoelzle, M., Paul, F., Haeberli, W Denzinger, F., Ahlstrøm, A.P., Anderson, B., Bajracharya, S., Baroni, C., Braun, L., Cáceres, B.E., Casassa, G., Cobos, G., Davila, L.R., Delagado Granados, H., Demuth, M., spizua, L.E., Fischer, A., Fujita, K., Gadek, B., Ghazanfar, A., Hagen, J.O., Holmlund, P. Karimi, N., Li, Z., Pelto, M., Pitte, P., Popovnin, V., Portocarrero, C., Prinz, R. Sangewar, C.V., Severskiy, I., Sigurdsson, O., Soruco, A., Usulbajev, R., Vincent, C., 2015 . Historically unprecedented global glacier decline in the early 21 st century. J. Glaciol. 61 (228), 745-762. 